\title{
OWNERSHIP AND ENFORCEMENT OF PATENT RIGHTS IN RUSSIA: PROTECTING AN INVENTION IN THE EXISTING ENVIRONMENT
}

If somebody invents any machine or process to speed up silkmaking or to improve it, and if the idea is actually useful, the inventor can obtain an exclusive privilege for ten years from the Guild Welfare Board of the Republic. ${ }^{1}$

\section{INTRODUCTION}

Since the collapse of the Soviet Union, Russia has been struggling with problems created by its unstable economy. The government sees the cure for the country's economy in Russia's accession to the World Trade Organization (WTO). ${ }^{2}$ The advantages of joining the WTO are clear: "Membership would create jobs, attract foreign investment, secure access to western markets on excellent trade terms and help to revive the output of

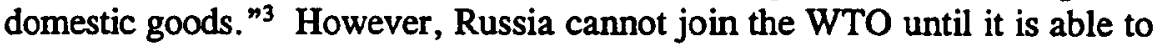
provide adequate protection for intellectual property (IP), which is one of the major WTO membership requirements. ${ }^{4}$ A survey conducted among U.S. companies showed that inadequate protection of trademarks and patents is "one of the four basic reasons preventing an influx of foreign investment capital to Russia." As U.S. Trade Representative Jeffrey Lang noticed: "So much of our trade is invested with intellectual property that we always have to look on this as an important issue."

Traditionally, Russia has been known for its disregard of IP rights. The Russian market is flooded with counterfeit products. For example, the

1. William H. Francis \& Robert C. Collins, Cases and Materials on Patent LAW 65 (4th ed. 1995) (quoting The Senate of Venice, 1400-1432).

2. The World Trade Organization created by Uruguay Round negotiations on January 1,1995, "is the only international body dealing with the rules of trade between nations." About the WTO (visited Nov. 22, 1997) <http://www.wto.org/wto/about/factso.htm > .

3. Bradford W.C. Price, Russia's Economic Future: A Step Towards Economic Recovery or Merely a Detour Towards Economic Absorption?, 4 J. INT'L L. \& PRAC. 571, 579 (1995).

4. Obligations of WTO members with respect to issues of intellectual property are covered by the Agreement on Trade-Related Aspects of Intellectual Property Rights (TRIPs Agreement). WTO Intellectual Property (visited Nov. 22, 1997) < http://www.wto.org/wto/ intellec/intel12.htm $>$.

5. Vladimir Zadera, Russia Faces Threat of Being Centre of Intellectual Piracy, TAss, Feb. 8, 1996, available in LEXIS, Europe Library, Tass File.

6. Jeffrey Lang, Remarks at the U.S.-Russia Business Council Conference (Apr. 1, 1997), available in LEXIS, Europe Library, SBE File [hereinafter Remarks by USTR Jeffrey Lang]. While in 1947 intellectual property accounted for only $10 \%$ of all American exports, in 1995 it accounted for more than 50\% of U.S. exports. Raymond Damadian, Patent System Faces Sabotage in Congress, NEWSDAY, Nov. 29, 1995, available in 1995 WL 5128525. 
number of authentic Reebok products sold in Russia is less than the number of imitation ones in the country. ${ }^{7}$ There are so many software pirates in Russia that the Business Software Alliance, a group of leading U.S. software companies, has called Russia a "one-copy" country, meaning that "one legitimate copy of a piece of software can satisfy the entire country." ${ }^{8}$ The situation regarding violation of patent rights is no better. In October 1997, SmithKline Beecham filed a lawsuit in the Moscow Arbitration Court to protect its patent covering the technology for producing Clavulanate, a key ingredient in the antibiotic Augmentin. ${ }^{9}$ The patent had been violated by a Slovenian company, Lek, which sells in Russia a drug identical to Augmentin. ${ }^{10}$ The Association of International Pharmaceutical Marketers, a group of forty international pharmaceutical producers in Moscow, claims that sales of counterfeit medicine is a big business in Russia where "lax intellectual property enforcement" allows offenders to go unpunished."

Current disregard of patent rights is rooted in the absence of patent protection under the old Soviet system. The former USSR ignored a fivecenturies-old, worldwide tradition of granting exclusive rights to a patent owner and replaced such protection with a system of "collective ownership of certified inventions protected by inventors' certificates of authorship," which allowed any Soviet organization to use an invention without its author's permission. ${ }^{12}$ Since the collapse of the Soviet system, Russia's goal has been to provide adequate protection for inventions and other intellectual property. Although the new Patent Law of the Russian Federation, adopted in September of 1992, conforms to international standards of patent legislation, "remnants of old Soviet practices still manifest themselves in the day-to-day experience of foreign investors in Russia."13 Yet, despite the

7. Astrid Wendlandt, High-Fashion Fakes Flood into Russia, Moscow TIMES, Apr. 3, 1996, available in LEXIS, Europe Library, Mostms File (quoting Sergei Lepatrikov, chief Reebok watchdog).

8. Karl Emerick Hanuska, Microsoft at the Gates to Confront Software Pirate-Infested Russia, AGENCE FRANCE-PRESSE, Oct. 9, 1997, available in 1997 WL 13410803 (quoting the Business Software Alliance).

9. Jeanne Whalen, SmithKline Beecham Files Lawsuit to Protect Patents, Moscow TimEs, Nov. 1, 1997. The patent was granted by the Russian Patent Office in June 1997. Id. "Augmentin (amoxicillin/clavulanate potassium) is a formulation of amoxicillin, which is a broad-spectrum penicillin, and clavulanate, which is a beta-lactamase inhibitor. . . . Augmentin is one of the world's most widely used antibiotics for infections in adults and children." SmithKline Beecham's Augmentin Cleared in U.S. (visited Jan. 17, 1998) < http:// www.pslgroup.com.1dg1623a.htm >.

10. Whalen, supra note 9.

11. Id.

12. Andrew A. Baev, Recent Changes in Russian Intellectual Property Law and Their Effect upon the Protection of Intellectual Property Rights in Russia, 19 SUFFOLK TRANSNAT'L L. REV. 361, 366 (1996).

13. Id. at 365 . 
existing problems, few established foreign companies are leaving Russia. Most foreign companies believe that "if reforms continue, opportunities justify the risks, uncertainties and considerable bureaucratic obstacles." 14 While "the enormous potential of Russia as a trading nation is not being met at this point," Russia nonetheless ranked thirty-fourth in U.S. export trade in 1995 , with $\$ 2.8$ billion in U.S. goods exported to Russia and $\$ 4$ billion in Russian imports to the United States. ${ }^{15}$ Recently, the Samara region of Russia, 530 miles southeast of Moscow, has attracted twenty-two U.S. companies, including General Motors, General Electric, Pepsico, Coca-Cola and others, to start operations there. ${ }^{16}$ "Microsoft's revenues from sales in Russia from July 1, 1996[,] to June 30, 1997, totaled 26.2 million dollars ... . ."17 Pushed by its desire to join the WTO, the Russian government has taken some steps to improve protection of IP rights in the country, including the adoption of the new Criminal Code, which imposes criminal liability for violations of IP rights and authorizes "police raids on street vendors offering counterfeit goods." 18 However, as U.S. Vice President Al Gore concluded during his visit to Russia in September 1997, Russia must make further improvements in the protection of IP rights in the country. ${ }^{19}$ The most severe problem faced by patent owners in Russia is the lack of a judicial structure capable of addressing complex patent disputes. Resolution of these and other legal and practical impediments is vital to Russia's ability to provide adequate protection of patent rights and requires immediate action from the Russian government.

This note discusses the protection of inventions in Russia's current environment. Part II begins by examining the legal protection of inventions in the former Soviet Union. The section then focuses on the current state of Russian patent legislation, including the first Patent Law of the Russian Federation, adopted in September 1992, and subsequent laws enacted between September 1992 and November 1997. Part II also compares Russian and U.S. patent statutes and examines the administrative and judicial systems available in Russia for resolving patent disputes. Part III discusses the practical implementation of the existing patent legislation. After

14. Investment Climate in Russia, RussIa EXPRESS BRIEFING, Sept. 30, 1996, available in 1996 WL 8618978.

15. Ivan Lebedev, There Are Still Some Obstacles to Russo-US Trade, TASS, Apr. 2, 1996, available in LEXIS, Europe Library, Tass File.

16. Richard C. Paddock, Gore Visits City on Volga to Promote Investment, L.A. TIMES, Sept. 25, 1997, available in 1997 WL 13983531.

17. Bill Gates, Russian Banking Giant to Discuss Automation Plans, AGENCE FRANCEPresse, Oct. 8, 1997, available in 1997 WL 13410124.

18. Michael Solton, Enforcing Intellectual Property Rights in Russia Remains Problematic, RuSS. \& COMMONWEALTH BUS. L. REP., Jan. 29, 1997, available in LEXIS, Europe Library, SBE File.

19. Paddock, supra note 16. 
acknowledging some of the positive steps taken by the Russian government to improve patent protection in the country, the section examines flaws in the current legislation and focuses on practical problems faced by patent owners in Russia. Three major practical impediments to businesses include: (1) inadequate enforcement of patent rights; (2) problems with inventions predating the current legislation; and (3) the lack of legal protection of Russian inventions abroad. While the problems with inventions developed prior to the new laws will become less critical with the passage of time, Russia's failure to enforce patent rights is the primary obstacle to its accession to the WTO and prevents the influx of foreign investments to the country. Furthermore, inadequate enforcement combined with the lack of protection of Russian inventions abroad hinders development of domestic innovations in Russia. Next, Part IV suggests ways to combat the aforementioned problems. While businesses themselves cannot create a workable enforcement mechanism, they should not wait passively for the government to eliminate the problems. Instead, they should use available legal means to protect their rights. Still, the problems cannot be effectively solved without the active involvement of the Russian government. The section suggests that in order to provide adequate patent protection, the Russian government should create an effective judicial infrastructure to adjudicate patent disputes. As the experience of progressive foreign countries demonstrates, the best solution would be to establish specialized patent courts. Finally, Part V concludes by addressing the importance of adequate patent protection in today's Russia.

\section{Legal AND Procedural Aspects of Protecting PATENT RightS IN RUSSIA}

\section{A. Before the New Patent Law: The Law of Inventions Under the Soviet System}

Private ownership of inventions was not recognized in the former Soviet Union. Although patent protection for inventions was formally available to inventors, in practice, Soviet inventors rarely applied for patents. Instead, the inventors applied for certificates of authorship. A certificate of authorship, a form unfamiliar to the western legal model, gave no legal protection to the inventors' rights. ${ }^{20}$ The issuance of the certificate actually rendered the state the owner of the invention, thereby giving the state all rights to use the invention in the USSR and abroad. ${ }^{21}$ Upon issuance of the certificate, the invention was transformed into "general state property"-any

20. ENCYCLOPEDIA OF SOVIET LAW 103 (F.J.M. Feldbrugee et al. eds., 2d ed. 1985).

21. Id. 
Soviet organization was allowed to use the invention without consulting the author. ${ }^{22}$ In return, a certificate holder received a number of benefits which actually made certificates more valuable than patents.

Not only did a certificate holder obtain social recognition and prestige from the right to be named the author of the invention, but he also received a monetary reward for the use of his invention, the right to a bigger apartment, and better scientific research positions at higher salaries. ${ }^{23}$ Certificates of authorship were indefinitely valid and could be challenged only within one year of issuance. ${ }^{24}$ By contrast, a patent's life was fifteen years and its validity could be attacked any time during its life. ${ }^{25} \mathrm{~A}$ certificate holder, unlike a patent holder, was not required to pay filing fees, issuance fees, or annuities. Moreover, non-technological inventions and all other inventions made in the course of employment with a Soviet organization could be protected only by certificates of ownership. ${ }^{26}$ Since at least eighty percent ${ }^{27}$ of all inventions were made in the course of employment, patent protection was not even an option for the overwhelming majority of Soviet inventors. ${ }^{28}$ Generally, patents were recognized "only in order to encourage foreigners to apply for Soviet legal protection of new technological solutions. ${ }^{29}$ Between 1970 and 1975, four patents were issued to Soviet inventors, compared to 203,046 certificates of authorship during the same time period. ${ }^{30}$

An application for a certificate of authorship could be submitted by an inventor or by his employer. ${ }^{31}$ The employer filed a joint application when the invention was made in the course of the employment. If the employer failed to file the application within one month after the invention was

22. O. IOFFE, Soviet Civil LAW 346 (1988). The term "general state property" (obshche gosudarstvennaya sobstvennost') was commonly used in relation to inventions and many other forms of property which are recognized as private property in the West. The notion of private property in the USSR was almost non-existent.

23. ENCYCLOPEDIA OF SOVIET LAW, supra note 20, at 103.

24. Id. at 104.

25. Id. at $103,563$.

26. IOFFE, supra note 22, at 344.

27. Baev, supra note 12, at 368.

28. Even when an invention was protected by a patent, a patent holder's rights were limited. The holder could neither refuse to license his invention when the state found its use "socially important," nor register or use his "patents abroad without approval of the Council of Ministers." ENCYClOPEDIA OF SOVIET LAW, supra note 20, at 563.

29. IOFFE, supra note 22, at 344 . After the USSR adhered to the Paris Convention, the number of foreign patents received in the USSR grew significantly. "About 10,000 foreigners hold patents obtained in the former Soviet Union." Baev, supra note 12, at 367 n.9.

30. George M. Armstrong, Invention and Innovation, in THE IMPACT OF PERESTROIKA ON SOVIET LAW 277 (Albert J. Schmidt ed., 1990).

31. InNa Boychuk, Soviet Patent Procedures: The Existing Process and the IMPACT OF THE NEW LAW 7 (1992). 
developed, the inventor was free to file an application independently ${ }^{32}$ All applications were processed by the State Committee for Inventions and Discoveries (Gospatent) or by the Scientific Research Institute for State Patent Examination (VNIIGPE). ${ }^{33}$ If the application was rejected, the inventor could appeal the examiner's action within two months after receiving the rejection notice. ${ }^{34}$ The same examiner reviewed the material supplied with an appeal and either sent a second rejection or invited the inventor to attend an examination conference. ${ }^{35}$ The examination conference, led by the same examiner, very rarely resulted in a reversal of the examiner's original decision because of the potential devastating effect on the examiner's career. ${ }^{36}$ Usually the inventor was convinced by the examiner to stop the appeal process and, as a result, would not exercise his final opportunity to appeal the examiner's decision to the Examination Control Council. Members of the Examination Control Council, an organ subordinate to Gospatent, analyzed the application independently of the examiner, but a ruling in the inventor's favor was rarely granted. ${ }^{37}$ Decisions of the Examination Control Council were final and could not be appealed. ${ }^{38}$ In practice, then, Soviet inventors lacked effective means to appeal rejections of their applications.

When a certificate of authorship or a patent was granted, all subsequent disputes, including "claims regarding the right to and amount of compensation, priority of authorship, alleged co-authorship, and patent infringement," were to be heard by the regular courts. ${ }^{39}$ However, cases involving governmental decisions on coercive purchases of licenses or patents, ${ }^{40}$ as well as cases involving state interests, were not within the courts' jurisdiction. ${ }^{41}$ In fact, judicial resolution of disputes related to

32. Id.

33. Id.

34. Id. at 28.

35. Id. at 29.

36. Id. at 30 . Only in $10 \%$ of cases was the examiner's original decision reversed because "VNIIGPE's internal rules consider[ed] the reversal of two rejection decisions as failing performance on the part of the examiner." Id.

37. Id. at 30-32. Since members of the Examination Control Council were reviewing a decision of Gospatent, to which they were subordinate, they did not want to risk their careers by reversing Gospatent's decision. Id.

38. Id. at 32.

39. ENCYCLOPEDIA OF SOVIET LAW, supra note 20, at 563 . The court's resolution, though, had to follow a preliminary decision "taken by the manager of the organization concerned, after consulting with the trade union or society of inventors . . . of the same organization." IOFFE, supra note 22 , at 349.

40. The government could decide that national interests allowed it to purchase a license or a patent without the consent of the patent owner; i.e., the government could decide to purchase a license or patent coercively. lOFFE, supra note 22, at 349.

41. Id. 
inventors' rights was so rare that “[i]t would be difficult . . . to illustrate application of these rules by citing cases from administrative or judicial practice in the USSR." 42

Generally, the Soviet system of inventions and intellectual property was absolutely incompatible with Western standards. It neither gave owners of inventions exclusive rights to use the inventions, nor encouraged people to respect the property rights of owners of inventions. After the end of the Soviet era, new laws were needed to turn an invention from "general state property" into the property of its actual owner, the inventor.

\section{B. From "General State Property" to Inventors' Exclusive Patent Rights: Current State of Patent Law in Russia}

The main legal document in Russian patent law today is the Patent Law of the Russian Federation (Patent Law), which was adopted on September 23, 1992, by the Fifth Session of the Supreme Soviet of the Russian Federation and went into force on October 14, 1992.43 Under the new law, the state is no longer the principal owner of inventions developed in Russia. With the enactment of the Patent Law, patents became the exclusive form of legal protection of inventions in Russia. Today, a Russian inventor can derive a profit from the use of his invention during the entire life of the patent, after which time the invention is available for public use without restrictions.

\section{Ownership of Patent Rights Under the First Patent Law of the Russian Federation}

The Patent Law provides protection to inventions, industrial designs, and utility models. ${ }^{44}$ Utility models, which were not protected under the Soviet law, include designs and constructions of industrial equipment and consumer goods and their components. ${ }^{45}$ The reason utility models ${ }^{46}$ were

42. Id. at 350 . According to published data, only 250 cases related to inventions were heard by courts annually in the entire Soviet Union. A.P. SERgeev, PatentNoe Pravo [PATENT LAW] 164 (1994). For reasons for such a low number, see infra notes 168-71 and accompanying text.

43. Mark Douma \& Rudolph Chistyakov, The First Patent Law of the Russian Federation, 1 U. BALT. INTELL. PROP. L.J. 162, 162 (1993).

44. Patentnii Zakon RF [RF Law of Patents Act] art. 1, Sobr. Zakonod. RF, 1992, No. 42, Item 2319, translated in RUSSICA, available in LEXIS, Intleg Library, Rusleg File [hereinafter Patent Law]. The author of this note who is a native of Russia uses the term "utility model," instead of the term "working model," which is used in the translated version, since "utility model" is a term commonly used in English legal literature.

45. Id. (art. 5). Utility models, which are not recognized in the United States, are given protection in over 30 countries, including Japan, Germany, and Italy. SERGEEV, supra note 
added to the Russian patent law was to encourage small private enterprises to produce much-needed domestic goods by giving them "fast, inexpensive protection of new product development." 47

A patent's life is twenty years for inventions, ten years for industrial designs, and five years for utility models. ${ }^{48}$ An invention is granted patent protection "if it is new, is up to invention standard, and is industrially applicable. ${ }^{n 99}$ Significantly, patentable inventions now include cell cultures and micro-organisms; this protection of medicines "alleviates one of the major complaints of foreigners." ${ }^{50}$ An industrial design is given patent protection if it is new, original, and industrially related. ${ }^{51}$ A certificate for a utility model is granted if the model is new and industrially related. ${ }^{52}$

The Russian law follows a first-to-file patent system. Such a system grants a patent to the first party to file a patent application in Russia or in a country participating in the Paris Convention if an application is subsequently filed in Russia within twelve months from the filing date in another country in the case of an invention or a utility model, or within six months in the case of an industrial design. ${ }^{53}$ Eighteen months after a patent application, or

42 , at 28 .

46. Utility models receive certificates, not patents. The Patent Law, in addressing issues of ownership and the enforcement of patent rights-the main focus of this paper-treats the holders of invention patents, industrial design patents, and utility model certificates equally.

47. Douma \& Chistyakov, supra note 43 , at 168.

48. Patent Law, supra note 44 (art. 3). Until recently, the patent monopoly term was 17 years in the United States. 35 U.S.C. $\$ 154$ (1952). Pursuant to recent amendments, patents granted on applications filed after July 8, 1995, have a term of 20 years. 35 U.S.C. $\S 154$ (1994). The term may be extended where commercialization is interrupted due to a delay in regulatory approval under the Food, Drug, and Cosmetic Act. 35 U.S.C. §§ 155-56 (1984). In the United States, designs (which are called "industrial designs" in Russian law) receive patent protection for a term of 14 years. 35 U.S.C. $\$ 173$ (1984).

49. Patent Law, supra note 44 (art. 4). The U.S. requirements that the invention has to be "new and useful," 35 U.S.C. $\S 101$ (1984), and non-obvious, 35 U.S.C. $\S 103$ (1984), are similar to the Russian definition.

50. Douma \& Chistyakov, supra note 43 , at 167 . Cell cultures and micro-organisms were not protected under the Soviet law because "patenting medicines was considered antisocial." Id.

51. Patent Law, supra note 44 (art. 6). In the United States, the patent is granted for a new, original, and ornamental design. 35 U.S.C. $\$ \$ 171,173$ (1984).

52. Patent Law, supra note 44 (art. 5).

53. Id. (art. 19). In contrast, the United States employs a first-to-invent patent system; it is "virtually the only nation left" that uses this system. G. Scott Erickson, Patent Protection for Central and Eastern Europe: Lessons from the West, in PRIVATIZATION AND ENTREPRENEURSHIP: THE MANAGERIAL Challenge IN CENTRAL AND EASTERN EUROPE 241, 246 (Arieh A. Ullman \& Alfred Lewis eds., 1997). The U.S. system grants the patent to the "true inventor" - the one who conceived the idea of the invention first-if the idea has first been reduced to practice and proven to be workable. Id. This system encourages risktaking and provides a better quality of innovation because it allows time "to prove out an idea[,] design it for optimal manufacturing, marketing, and legal purposes[,] and then file a 
"claim," is filed-if the result of the formal examination was positive and the claim has not been revoked-the Patent Office will publish the "information on the claim," after which time any person is entitled to view its materials. ${ }^{54}$ Between the time of publication and the time the patent is issued, the invention receives "temporary protection in law." 35 A party using the invention during this period has to pay compensation to the patent owner after the issuance of the patent. ${ }^{56}$ The patent owner will be compensated for the use of the invention from the date of publication or from the date when the user of the invention receives notice that the application has been filed, whichever date is earlier. ${ }^{57}$ The validity of patents can be attacked any time during their life. A patent may be terminated if it is invalidated, if the patent owner files the petition with the Patent Office, or if maintenance fees have not been paid. ${ }^{58}$

Under the Patent Law, a person is deemed the author of an invention ${ }^{59}$ only if the invention is a result of his creative efforts. A person is not considered to be the author if he, with no creative contribution of his own, merely gave the author technical, organizational, or financial assistance or helped the author to obtain or use the patent. ${ }^{60}$ If the invention has more than one author, they must come to an agreement on how to use their rights of authorship. ${ }^{61}$ In practice, co-authors are not always able to reach an

strong patent application." Id. at 248.

54. Patent Law, supra note 44 (art. 21(6)). Upon the applicant's request, the Patent Office can publish information on the claim "before the aforesaid date." Id.

55. Id. (art. 22(1)-(2)). Temporary protection will not be granted if the application is rejected and appeals are exhausted. Id.

56. Id. (art. 22(3)). The amount of the compensation will be defined by the agreement between the parties. This agreement, while similar to the license agreement in form, will differ from the license agreement in substance for two reasons: (1) at the time of use the patent has not yet been issued, so the applicant did not have a right to refuse use of the invention; and (2) the agreement should not be registered with the Patent Office. S.P. GrishaEV, PRAVOVAYA OKHRANA IZOBRETENII, PROMISHLENNIKH OBRAZTSOV, POLEZNIKH MODELEI V ROSSII I ZA RUBEJOM [LEgAL PROTECTION OF INVENTIONS, INDUSTRIAL DESIGNS, AND UTILITY MODELS IN RUSSIA AND ABROAD] 33 (1993). For a detailed discussion of license agreements, see infra notes 86-88 and accompanying text.

57. Patent Law, supra note 44 (art. 22(4)). "Thus, the effective term of a patent is 20 years only in the case where the applicant notifies possible infringers on the filing date of the application. Publication on schedule without further action would result in an 18.5 year effective term." Douma \& Chistyakov, supra note 43, at 179 n.124.

58. Patent Law, supra note 44 (art. 30 ).

59. Hereinafter, the word "invention" will also include "industrial design" and "utility model," unless indicated otherwise.

60. Patent Law, supra note 44 (art. 7). This provision is similar to the U.S. law under which a person is not the author if "he did not himself invent the subject matter sought to be patented." 35 U.S.C. § 102(f) (1984).

61. Patent Law, supra note 44 (art. 7(2)). The U.S. law is different: applicants do not have to agree among themselves before filing the application. A joint inventor is permitted 
agreement. ${ }^{62}$ Thus, before filing a patent application, they will have to rely on a court for resolution of the issue; otherwise, they may be subjected to criminal liability for misappropriation of authorship or for unauthorized disclosure of information on an object of industrial property. ${ }^{63}$ Under the first-to-file patent system, where an early priority date is important, the recommendation is to "file, naming all inventors, and to be prepared to withdraw the application before it is published. ${ }^{n 4}$

Article 8 of the Patent Law defines the rights of patent owners. A patent owner may be an author, the author's employer, or a person assigned by the author in the application or in a written declaration filed with the Patent Office before the patent is issued. ${ }^{65}$ Article 8 is mainly devoted to issues concerning inventions made in the course of employment. In resolving the many disputes concerning these issues, lawmakers gave priority to the interests of employers in order to create incentives for employers to support the development of inventions. ${ }^{66}$ Thus, the right to obtain a patent for an invention created in the course of employment belongs to the employer unless there is an agreement to the contrary. However, the employer must compensate the employee in proportion to the profit which is received, or which could have been received, when the employer does any of the following: obtains the patent; assigns the right to obtain the patent to a third party; decides to keep the invention secret; or receives a rejection on the application for reasons within its control. ${ }^{67}$ On the other hand, if the employer, within four months after the employee informed the employer about the invention, "fails to: (1) seek a patent, or (2) assign his right to file an application to a third party, or (3) notify the employee that he has decided to keep the invention secret, ${ }^{n 68}$ then the employee himself has the right to

to apply without the other inventor. 35 U.S.C. $\$ 116$ (1984).

62. GRISHAEV, supra note 56, at 34-35.

63. Patent Law, supra note 44 (art. 32). The U.S. law is less stringent; it allows an inventor to execute an application if he can show "sufficient proprietary interest in the matter" and that "such action is necessary to preserve the rights of the parties or to prevent irreparable damage." 35 U.S.C. § 118 (1984).

64. Douma \& Chistyakov, supra note 43 , at 169 . Douma and Chistyakov have noted that, according to their private communications with Valentin M. Oushakov and Vladimir A. Mescheryakov from the Department of Foreign Communications at the Russian Patent and Trademark Office, such an application would be allowed. Id. at 179 n.56.

65. Patent Law, supra note 44 (art. 8(1)). While in the United States the employee/ employer relationship is defined by common law rules, in Russia it is entirely statutory. Douma \& Chistyakov, supra note 43, at 170 . See also ROBERT L. HARMON, PATENTS AND THE FEDERAL CiRCUIT 251-52 (3d ed. 1994).

66. GRISHAEV, supra note 56 , at 37 . This approach is in accordance with the one accepted worldwide. Id.

67. Patent Law, supra note 44 (art. 8(2)). A translation reads: "for reasons beyond the employer's control." However, this language does not correspond to the original.

68. Douma \& Chistyakov, supra note 43 , at 170. 
obtain the patent. The employer will still be able to use the invention in its operations, but it will have to compensate the patent owner according to the agreement between them. If the parties fail to reach an agreement, or if the employer breaches the agreement, a civil court will resolve the dispute between them. ${ }^{69}$

A patent owner has exclusive rights to use the invention if his use does not result in an infringement of other patent owners' rights. A joint patent owner can use the patent independently but cannot assign or license it without the consent of the other owners. ${ }^{70}$ Infringement of a patent owner's rights occurs in cases of unauthorized making, use, import, offer for sale, sale, or any other form of marketing or storage of the invention for the purpose of making a sale. ${ }^{71}$ Use of a patented process, or the marketing or storage of a product made by a patented process, also constitutes infringement, and a new product is presumed to be made by a patented process unless there is proof otherwise. ${ }^{n}$ Thus, the burden is on the defendant to establish that the product was not made by a patented process.

The patent owner's exclusive right is not, however, absolute. The first limitation applies when the patent owner fails to use the patent or inadequately uses it during the four years ${ }^{73}$ after the patent was issued. If another person is willing and ready to use it, but the patent owner refuses to enter into a license contract with him, the would-be user can apply to the Supreme Patent Chamber for a non-exclusive license, which will be granted if the patent owner fails to present a sufficient excuse for his actions. ${ }^{74}$ The terms of the license will be fixed by the Supreme Patent Chamber. ${ }^{75}$ A

69. Patent Law, supra note 44 (art. 8(2)).

70. Id. (art. 10(1)). Cf. 35 U.S.C. $\$ 262$ (1984) (emphasis added): “In the absence of any agreement to the contrary, each of the joint owners of a patent may make, use, offer to sell, or sell the patented invention ... without the consent of and without accounting to the other owners."

71. Patent Law, supra note 44 (art. 10(3)). The U.S. law is narrower: acts of infringement are limited to unauthorized making, use, offer for sale, sale, and import of a patented invention. 35 U.S.C. \$ 271 (1994).

72. Patent Law, supra note 44 (art. 10(3)). Under the U.S. law, the product is presumed to be made by a patented process "if the court finds-(1) that a substantial likelihood exists that the product was made by the patented process, and (2) that the plaintiff has made a reasonable effort to determine the process actually used in the production of the product and was unable so to determine." 35 U.S.C. $\$ 295$ (1994).

73. Patent Law, supra note 44 (art. 10(4)). The limitation for the use of a utility model is three years. Id.

74. Id. The purpose of this limitation, used all over the world, is to prevent companies that hold patents from refusing to utilize them, thereby impeding industrial progress. GRISHAEV, supra note 56 , at 41 .

75. Patent Law, supra note 44 (art. 10(4)). "Market value will be determined as in the U.S. through expert testimony." Douma \& Chistyakov, supra note 43, at 172 (referring to private communications with Oushakov and Mescheryakov). 
second limitation allows one patent owner to demand from another patent owner the conclusion of the license contract when the former cannot use his invention without infringing patent rights of the latter. ${ }^{76}$ This provision is not explained and it may be dangerously interpreted to mean that "a minor improvement by a second inventor theoretically gives him the right to a license without a reciprocal requirement to license the first." $\pi$ A third limitation is codified in Article 12 of the Patent Law: prior users who, in good faith, began using or made necessary preparations for the use of the "identical solution" before the priority date of the invention "shall retain the right to further gratuitous use thereof." ${ }^{78}$ However, the scope of this use may not be expanded. Moreover, the right of prior use may be assigned to others only with the transfer of the production facility; i.e., this right can only be used for purposes of the prior user's business and may not be a subject of licensing or other independent agreements. ${ }^{79}$ A fourth limitation allows unauthorized use of patented inventions in the following situations: (a) in the construction or operation of transportation facilities in a foreign country which provides similar privileges to Russian facilities, when the foreign transportation facilities enter the territory of the Russian Federation temporarily or accidentally; ${ }^{80}$ (b) in conducting scientific research or experiments involving a matter containing the patented invention; ${ }^{81}$ (c) in using matters containing patented inventions in emergency situations with subsequent commensurate compensation to the patent owner; (d) in using matters containing patented inventions "for personal purposes, without gain"; 82 (e) in "one-off preparation of drugs in pharmacies on doctor's prescription"; and $(f)$ in using matters containing patented inventions where these matters were legitimately introduced into commerce ${ }^{83}$ (i.e., "one may use or resell an invention purchased from a patent owner" ${ }^{\text {84 }}$ ). Finally, " $[\mathrm{i}] \mathrm{n}$ the interests of national security," the government of the Russian Federation

76. Patent Law, supra note 44 (art. 10(5)).

77. Douma \& Chistyakov, supra note 43 , at 173.

78. Patent Law, supra note 44 (art. 12).

79. Id. See also GRISHAEV, supra note 56, at 42.

80. This provision is in accordance with Article 5 of the Paris Convention and with 35 U.S.C. $\$ 272$ (1984).

81. This exception was "meant to legalize reproduction of the invention in order to understand and improve it and does not allow making and selling." Douma \& Chistyakov, supra note 43, at 171 (referring to private communications with Vladimir Shitikov, director of the Department of Licensing at the Russian Patent and Trademark Office).

82. The U.S. Law also allows a person "to make or use a patented invention if her purpose is only to satisfy her scientific curiosity or to amuse herself as an intellectual exercise," but not if the person "has a commercial motivation, or motivation to selfconvenience." MARGReTH BARRETT, INTELLECTUAL PROPERTY 56 (2d ed. 1996).

83. Patent Law, supra note 44 (art. 11).

84. Douma \& Chistyakov, supra note 43 , at 171 (citing private communications with Vladimir Shitikov). 
may permit a non-owner to use the patented invention without its owner's consent, as long as he pays the owner "commensurate compensation." 85

A patent owner may assign his exclusive right to use the patent to any person, as long as the assignment is registered with the Patent Office. ${ }^{86} \mathrm{~A}$ patent owner can also grant the use of his patent to another by entering into a licensing agreement with that person. Under an exclusive license, a licensee obtains the exclusive right to use a patented invention within the limits specified in the agreement. Under a non-exclusive license, the patent owner, while granting the licensee the right to use the invention, retains all of his patent rights, including the right to license his patent to a third person. ${ }^{87}$ A patent owner may also obtain an "open license" by notifying the Patent Office that he would be willing to grant a license to any interested party. The offer to grant the license is irrevocable. ${ }^{88}$

Patent applications for inventions created in the Russian Federation can be submitted to countries abroad no earlier than three months after filing a claim with the Patent Office. ${ }^{89}$ Foreign persons and entities enjoy equal rights with Russian citizens under international treaties or under the principle of reciprocity..$^{90}$ Where the Patent Law conflicts with international treaties of the Russian Federation, international treaties will prevail.91

While the Patent Law of the Russian Federation remains the principal legal document in the area of patent law, other legislative provisions enacted after the Patent Law also play an important role in this area of the law.

85. Patent Law, supra note 44 (art. 13(4)).

86. Id. (art. 10(0)). While U.S. law renders an assignment that was not recorded in the Patent and Trademark Office "void as against any subsequent purchaser or mortgagee for a valuable consideration, without notice," 35 U.S.C. $\$ 26$ (1984), Russian law renders such assignment a legal nullity.

87. Patent Law, supra note 44 (art. 13(1)). "U.S. licensees should note that Russian law goes further than U.S. law in requiring that a license, even a non-exclusive one, must also be recorded." Douma \& Chistyakov, supra note 43, at 169.

88. Patent Law, supra note 44 (art. 13(3)).

89. Id. (art. 35). "The purpose is to allow the Patent Office to determine if the invention should be kept secret." Douma \& Chistyakov, supra note 43, at 179 n.96.

90. Patent Law, supra note 44 (art. 36). Despite their equal status, "the foreign applicants to acquire patent and trademark rights have to conduct the business through patent attorneys registered with [the] Patent Office (except those from . . . most . . . CIS countries)." Alexander A. Christophoroff, Protection of Intellectual Property in Russia (visited Nov. 19, 1997) <http://www.ruslaw.ru> .

91. Patent Law, supra note 44 (art. 37). "Russia is a party to the Paris Convention, the Patent Cooperation Treaty, Madrid Agreement (acceding to the Madrid Protocol is also planned), the Universal Convention and Berne Convention, and some other multilateral and bilateral treaties." Christophoroff, supra note 90. 


\section{Other Laws Impacting Protection of Patent Rights in Russia}

The Russian patent law system is continually developing. During the five years following the adoption of the first Patent Law, Russia adopted several other legislative acts which impacted the protection of patent rights.

In the former Soviet Union, over ninety-nine percent of inventions and industrial designs were protected by certificates of authorship. ${ }^{92}$ Certificates predating the Patent Law of the Russian Federation still remain in effect. ${ }^{93}$ However, the Russian government did adopt a decree regulating the use of inventions and industrial designs protected by certificates of authorship. ${ }^{94}$ The decree provides that use of such an invention or industrial design by any entity is considered use without a required permit. ${ }^{95}$ Any entity that uses the invention before the twenty-year expiration date ${ }^{96}$ (from the date the application for the certificate was filed) and after the decree was enacted must notify the author within three months from the day it begins using the invention, and must pay compensation to the author according to the agreement between them. ${ }^{97}$ If use of the invention began before the decree was enacted, the compensation is to be paid in conformity with the law effective at the time the use began, but its amount is to be increased according to the existing rate of inflation. ${ }^{98}$

Despite the new Patent Law, some provisions of the former Soviet legislation are still in effect in the Russian Federation. The USSR Law on

92. See supra notes $20-29$ and accompanying text.

93. Certificates of authorship and patents issued in the former Soviet Union are effective in the Russian Federation unless: (1) they are deemed invalid under the law effective at the time an application for a certificate was filed, or (2) they have been exchanged for patents. O Vvedenii v Deistvie Patentnogo Zakona RF [Enacting RF Law of Patents Act], Sobr. Zakonod. RF, 1992, No. 42, Item 2320, translated in RUSSICA, available in LEXIS, Intleg Library, Rusleg File. Where a party begins using the invention protected by the certificate of authorship before the certificate owner applies for a patent, the party has a right to continue using the invention without entering into a licensing agreement with the patent owner. The amount of compensation is defined in conformity with the law effective at the time the use of the invention begins. Id. $\S 8$.

94. O Poryadke Ispol'zovaniya Izobretenii I Promishlennikh Obrastzov, Okhranyaemikh Deistvuyushimi na Territorii RF Avtorskimi Svidetel'stvami na Izobretenie I Svidetel'stvami na Promishlennii Obrasez, I Viplati ikh Avtorami Voznagrajdeniya [Use of Inventions and Industrial Designs Protected by Certificates of Authorship in Effect on RF Territory and Payment of Compensation to their Authors], Sobr. Zakonod. RF, 1993, No. 29, Item 2681, translated in RUSSICA, available in LEXIS, Intleg Library, Rusleg File [hereinafter Use of Inventions Protected by Certificates of Authorship].

95. Id. $\S 1$.

96. In the case of an industrial design, the term is 15 years. Id.

97. Id. Every person or entity using the invention has to pay compensation, the amount of which is defined by the agreement between the parties and does not have any limits. Id.

98. Id. $\S 2$. Compensation paid before this decree was enacted is not subject to recalculation. Id. 
Inventions still applies in the following situations: (1) in establishing benefits and material incentives for inventors; (2) in the state's contracting for delivery of products for the state's needs (where the products utilize patented inventions owned by other citizens or enterprises, including foreign patent owners); (3) in calculating the compensation to be paid to the author of an invention where the author and his employer that owns the patent cannot reach an agreement as to the amount of compensation; and (4) in awarding compensation to be paid by enterprises to persons giving assistance in the creation and use of inventions. ${ }^{99}$

On February 12, 1993, a new statute was enacted creating the Committee of the Russian Federation on Patents and Trademarks (Rospatent) as a central agency of the federal executive power in the area of intellectual property protection. ${ }^{100}$ The statute defines the functions and goals of Rospatent's activity. ${ }^{101}$ The Chairman of Rospatent is appointed by the President of the Russian Federation, ${ }^{102}$ and the Board of Rospatent has to be approved by the government. To promote efficiency in the filing of patent applications and the maintenance of patents, the government enacted a statute creating a new class of professionals called "patent agents." 103 A patent agent is a citizen who successfully passes an examination administered by Rospatent and thereby obtains the right to represent an individual or an organization before Rospatent or any other organization that is part of the patent system. ${ }^{104}$ A patent agent must have a bachelor's degree, must have at least four years of work experience in the area of intellectual property or in the general law-an attorney or other person allowed to engage in law practice would probably qualify - and must know Russian and international laws necessary for practicing in this area. ${ }^{105}$

99. O Poryadke Primeneniya na Territorii RF Nekotorikh Polojenii Zakonodatel'stva Bivshego SSSR ob Izobreteniyakh I Pormishlennikh Obraszakh [Application on RF Territory of Some Provisions of Ex-USSR Legislation on Inventions and Industrial Designs], Sobr. Zakonod. RF, 1993, No. 34, Item 3191, translated in RUSSICA, available in LEXIS, Intleg Library, Rusleg File.

100. Polojenie o Komitete RF po Patentam I Tovarnim Znakam [Statute of the RF Committee on Patents and Trademarks], Sobr. Zakonod. RF, 1993, No. 8, Item 655, translated in RUSSICA, available in LEXIS, Intleg Library, Rusleg File.

101. Id. §§ 4-5. In addition to functions similar to those performed by the U.S. Patent and Trademark Office, Rospatent has to frame proposals for shaping the uniform state policy in the area of IP protection and for improving legislation in this area, and must provide educational programs for specialists in this area. Id. See also 35 U.S.C. $\S \S 1,2,6,9$ (1984).

102. In the United States, the Commissioner of patents is also appointed by the President, but with the advice and consent of the Senate. 35 U.S.C. $\$ 3$ (1984).

103. Polojenie o Patentnikh Poverennikh [Statute of Patent Agents], Sobr. Zakonod. RF, 1993, No. 7, Item 573, translated in. RUSSICA, available in LEXIS, Intleg Library, Rusleg File.

104. Id. $\$ 1$.

105. Id. § 2. Cf. 37 C.F.R. § 10.7: One must be "possessed of the legal, scientific, and 
The Russian Federation Law on Competition and Restriction of Monopolistic Activities in Commodities Market gives legal protection to patent owners if violation of their rights can be classified as unfair competition. ${ }^{106}$ Some forms of unfair competition for which the law gives relief are: (1) "circulating false, inaccurate or distorted information" capable of causing losses to another business entity or "damaging its business reputation"; (2) "misleading consumers" about the nature, method and place of manufacture, consumer properties, and quality of a product; and (3) "obtaining, using or disclosing" scientific, technical, production-related, "or trading information, including commercial secret, without the owner's consent. ${ }^{107}$ Thus, where patent infringement results in unfair competition, the patent owner may resort to the anti-monopoly law.

The new Russian Criminal Code, which became effective on January 1, 1997, imposes criminal penalties for the unlawful exploitation of a patent; the unauthorized divulgence of the nature of an invention, industrial design, or utility model before its publication; the misappropriation of authorship; or the obtaining of co-authorship by compulsion. ${ }^{108}$ The penalties include: a fine 200 to 500 times greater than the minimum wage, a fine equal to two to four months of the infringer's income, 180 to 240 hours of mandatory labor, or imprisonment for up to two years. ${ }^{109}$ However, criminal liability is imposed only if an infringer caused "significant damages." 110 Repeat infringers and group conspirators receive greater punishment. ${ }^{11}$

Finally, the Edict of the President of the Russian Federation, issued on September 11, 1997, requests the formation, in the Patent and Trademark Office (Rospatent), of an entity to carry out the functions of the Supreme Patent Chamber. ${ }^{112}$ Accordingly, the government, in its decree of September

technical qualifications necessary to enable him or her to render applicants for patents valuable services." A patent agent in the United States is one who successfully passes the Patent Agent's Exam, administered by the Patent and Trademark Office, but who is not an attorney. Id.

106. O Konkurenzii I Ogranichenii Monopolisticheskoi Deyatel'nosti na Tovarnikh Rinkakh [RSFSR Competition and Restriction of Product Market Monopoly Act] § III, art. 10, Sobr. Zakonod. RF, 1991, No. 16, Item 499, translated in RUSSICA, available in LEXIS, Intleg Library, Rusleg File [hereinafter Anti-Monopoly Law]. For details on the application of the Anti-Monopoly law, see infra notes 220-26 and accompanying text.

107. Anti-Monopoly Law, supra note 106, \& III, art. 10.

108. UK RF [Criminal Code of RF], Sobr. Zakonod. RF, 1996, No. 25, Item 2954, Art. No. 147, available in CONSULTANTPLUS (visited Oct. 13,1997) < http://www.consultant. ru>.

109. Id.

110. Id.

111. Id. Greater punishment includes a fine of $400-800$ times the minimum wage, a fine equal to four to eight months of the infringer's income, arrest for four to six months, or imprisonment for up to five years. Id.

112. Ukaz Presidenta RF O Rossiiskom Agenstve po Patentam I Tovarnim Znakam [RF 
19,1997 , ordered that Rospatent, in cooperation with the Ministry of Justice, present to the Russian government a proposal for the formation of such an entity. ${ }^{113}$ This proposal was to be presented to the Russian government within three months from the date of the decree. Thus, the actual establishment of the Supreme Patent Chamber, the absence of which has generated numerous complaints over the last five years, is becoming a reality.

The Supreme Patent Chamber is supposed to be a part of the administrative system designed to adjudicate certain types of patent disputes. Currently, courts resolve patent disputes that are not within the jurisdiction of administrative organs. Some serious problems concerning the protection of patent rights are closely related to the existing structure of both the administrative and judicial systems. ${ }^{114}$

\section{Administrative and Judicial Systems of Patent Adjudication}

Under the Russian Patent Law, some patent disputes can be resolved only by administrative proceedings. When the Patent Office establishes, during preliminary examination, that the subject matter of the claim is not patentable, the applicant may appeal to the Chamber of Patent Appeals within two months. ${ }^{115}$ The Chamber of Patent Appeals must then render a decision within two months of the date of appeal. If the application was rejected during substantive examination, the appellant has three months to appeal the Patent Office's decision to the Chamber of Patent Appeals, which then has four months to render a decision. ${ }^{116}$ This decision may be appealed

President's Edict on the Russian Patent and Trademark Agency], Sobr. Zakonod. RF, 1997, No. 37, Item 4267, translated in RUSSICA, available in LEXIS, Intleg Library, Rusleg File.

113. O Rossiiskom Agenstve po Patentam I Tovarnim Znakam I Podvedomstvennikh emu Organizaziakh [Statute on Patent and Trademark Office and its Subordinate Organizations], Ross. Gazeta, Oct. 7, 1997, available in CONSULTANTPLUS (visited Oct. 26, 1997) <http://www.consultant.ru>.

114. See infra notes $151-55$ and $172-83$ and accompanying text.

115. Patent Law, supra note 44 (art. 21(3)). The U.S. patent process does not have the step of preliminary examination. Unlike the Russian Patent Office, the U.S. Patent Office can itself institute interference proceedings over patentability issues (i.e., when it needs "to determine who was the first to invent, and therefore entitled to patent an invention, when two or more applicants claim the same invention"). John B. Pegram, Should the U.S. Court of International Trade Be Given Patent Jurisdiction Concurrent with That of the District Courts?, 32. Hous. L. REV. 67, 97 (1995).

116. Patent Law, supra note 44 (art. 21(8)). A U.S. applicant can appeal to the Patent and Trademark Office's Board of Appeals after his application has been twice rejected or finally rejected by the Patent and Trademark Office's patent examiners, or in any interference proceeding over which the Patent and Trademark Office has jurisdiction. Clifford A. Ulrich, The Patent Systems Harmonization Act of 1992: Conformity at What Price?, 16 N.Y.L. SCH. J. INT'L \& COMP. L. 405, 412 (1996). 
within six months to the Supreme Patent Chamber, whose decision is final. ${ }^{117}$ If a patent was issued and then invalidated because it either failed to meet the conditions of patentability or because the patent's claim was inconsistent with the patent's description, the invalidation may be appealed to the Chamber of Patent Appeals, which will render its decision within six months. ${ }^{118}$ Again, the decision of the Chamber of Patent Appeals may be appealed within six months to the Supreme Patent Chamber, whose decision is final. In addition, the law assigns to the Supreme Patent Chamber exclusive jurisdiction over the following classes of cases: (1) disputes arising when a party wants to obtain a non-exclusive compulsory license for use of a patented invention which was not sufficiently used by its owner; ${ }^{119}(2)$ disputes over terms of the agreement in the case of an open license; ${ }^{120}$ and (3) disputes over compensation paid to a patent owner whose invention will be used without his consent upon permit from the government. ${ }^{121}$

The civil courts have jurisdiction over all other disputes, including those arising over inventorship, patent ownership, patent infringement, licensing contracts, rights of prior users of patented inventions, and inventions created in the course of employment. ${ }^{122}$ A dispute in which at least one party is a physical person, and not a legal entity, can be resolved by a court of general jurisdiction. Arbitration courts adjudicate disputes between "legal entities and/or businessmen." ${ }^{23}$ A lawsuit can be filed in a court in the district ${ }^{124}$ in which the defendant is situated (the place of residence if the defendant is an individual, or the location of the business or property if the defendant is an organization), or where the contract is performed (if the lawsuit is based on a contract). ${ }^{125}$ The prerequisite for the

117. Patent Law, supra note 44 (art. 21(9)). The United States Court of Appeals for the Federal Circuit (CAFC) has appellate jurisdiction over all appeals from the Board of Patent Appeals. 37 C.F.R. $\S 1.614$ (1995). CAFC decisions, in turn, are reviewable by the Supreme Court of the United States. Id.

118. Patent Law, supra note 44 (art. 29).

119. See supra notes 74-75 and accompanying text.

120. See supra text accompanying note 88.

121. See supra text accompanying note 85 .

122. Patent Law, supra note 44 (art. 31).

123. Christophoroff, supra note 90 . Arbitration courts only resolve disputes over economic matters. C.A. GorlenKo et al., PRAVOVAYA OKHRANA INTEllekTUAL'NOI SOBSTVENNOSTI [LEGAL PROTECTION OF INTELLECTUAL PROPERTY] 193 (1995). In the United States, patent disputes are adjudicated by federal district courts. Pegram, supra note 115, at 70.

124. The meaning of "district" in Russia is different. It is closer to "county." For example, St. Petersburg, a city with a population of five million, is divided into more than 10 districts, each with its own court of general jurisdiction.

125. GORLENKo ET AL., supra note 123, at 194. A plaintiff does not have to file a lawsuit in a lower court (district court). A higher court can adjudicate in the first instance a dispute over which a lower court has jurisdiction. Even the highest Russian court, the 
court's adjudication of a patent dispute, except disputes over compensation paid to inventors for inventions created in the course of employment, is the existence of a patent for an invention or industrial design, or of a certificate for a utility model. ${ }^{126}$ Since patent rights disputes are usually complex and require specific technical and scientific knowledge, courts appoint their own experts. ${ }^{127}$ The court's decision is binding on all persons and entities involved and must be followed throughout the entire territory of the Russian Federation.

\section{Practical Implementation of Legal Changes}

The practical implementation of the recent changes in patent owners' rights has not been accomplished easily in Russia. One of the major obstacles to Russia's admission to the WTO has been its inadequate protection of intellectual property rights, including protection of patent owners' rights. ${ }^{128}$ Although serious problems still remain, some positive advances can be seen in this area. Although acting more slowly than the United States and other western countries would like, Russia is taking steps to improve protection of patent owners' rights.

\section{A. Overcoming Obstacles to Accession to the World Trade Organization: The Slow Improvement of Patent Rights Protection in Russia}

It has been five years since Russia adopted its first Patent Law, which is generally recognized as "a world-class intellectual property law." 129 The procedure for obtaining a patent under this law is similar to the one in the United States and has proved to be workable. In 1995, Rospatent processed more than 24,000 patent and trademark applications. ${ }^{130}$ According to official

Supreme Court of the Russian Federation, can adjudicate a patent dispute in the first instance if it so chooses. SERGEEv, supra note 42 , at 24 . However, the plaintiff's desire to file suit with the higher court is not enough-after the plaintiff files a complaint with the higher court, the court determines whether it will hear the case or not. GoRLENKO ET AL., supra note 123, at 195 .

126. GORLENKO ET AL., supra note 123, at 195.

127. Id. at 196. This differs from the U.S. judicial system in which parties to the lawsuit are allowed to use their own experts. Id.

128. Bruce A. McDonald, Protection of Technology Transfers and International IP Agreements, 6 CENT. EUR. BUS. GUIDE 5 (May 1, 1996), available in 1996 WL 8665105.

129. Remarks by USTR Jeffrey Lang, supra note 6. See also Russia Adopts Statement on Intellectual Property Protection, 8 NO. 4 J. PROPRIETARY RTS. 29 (1996) [hereinafter Statement on IP Protection]; and Baev, supra note 12, at 371.

130. Clamping Down on Russian Piracy, LAWYER INTERNATIONAL 7, June 1, 1996, available in 1996 WL 9610794 . This number is especially significant if compared with the five to seven applications processed in the former Soviet Union ten years ago, id, and with the four patents received by Soviet inventors between 1970 and 1975. See supra Part II.A. 
Russian statistics, as of January 1, 1996, 76,186 patents for inventions, 4700 patents for industrial designs, 1339 certificates for utility models, and 92,915 trademarks were maintained in Russia. ${ }^{131}$ Patent agents are now available to assist inventors in filing patent applications and in maintaining patents. ${ }^{132}$

As of January 1, 1996, inventions can also be protected in the former Soviet republics under a common Eurasian patent document. ${ }^{133}$ A favorable decision on one application filed in the Eurasian Patent Office in Moscow has ensured protection of the invention in all countries belonging to the Eurasian Patent Convention (EAPC). ${ }^{134}$ Today, a foreign or a native applicant who wants to obtain a patent in the former Soviet republics needs only to be familiar with one legal procedure and one language. ${ }^{135}$

The new law imposing criminal liability for patent infringement demonstrates that Russia is making progress in providing adequate protection of patent rights. ${ }^{136}$ Fear of imprisonment has a much greater deterrent effect on would-be infringers than do fines and penalties. "The adoption of the new Criminal Code brings Russia one step closer to compliance with the provisions of the Agreement on Trade-Related Aspects of Intellectual Property (TRIPs) and to its accession to WTO."137

Improvement in the protection of patent owners' rights is also demonstrated by Russia's taking action to enforce existing laws. ${ }^{138}$ According to the Economic Crime Department of the Interior Ministry,

131. B.A. Lobach, Chem Chrevato Narushenie Patentnikh Prav [Consequences of Patent Infringement], PATENTI I LIZENSII [PATENTS AND LICENSES], No. 8 (1996) [hereinafter Lobach 1]. Foreign firms register 2500 patents in Russia annually. Russia: Specialists Notice Low Level of Intellectual Property Protection, DELovor MIR, Mar. 26, 1997, available in 1997 WL 92972093 [hereinafter Low Level of IP Protection].

132. See supra notes $103-05$ and accompanying text.

133. Russia: Inventions Will Be Protected in the Former Soviet Republics with a Common Eurasian Patent Document, MOSKOVSKIE NovosTI, Feb. 14, 1996, available in 1996 WL 9207687 [hereinafter Eurasian Patent].

134. Eurasian Patent Convention-New Regional System for Protection of Patent Rights, PATENTS-DESIGNS-TRADEMARKS-LITIGATION (Sojuzpatent, Moscow, Russia), Mar. 1996, at 1. As of March 1996, the Eurasian patent covers two-thirds of the territory of the former Soviet Union, including Azerbaijan, Belarus, Kazakhstan, Russia, Tajikistan, Turkmenistan, Kyrgystan, Moldova and Armenia. Id. at 2.

135. Only the Russian text of the patent application is required. Id. The cost of obtaining a Eurasian patent is $\$ 2100$. See Eurasian Patent, supra note 133.

136. For more details on this statute, see supra notes 108-11 and accompanying text.

137. Solton, supra note 18. "More and more people in Russia are beginning to realize that intellectual property costs a lot of money and that 'thieves' must be punished and face both criminal and material sanctions." Alexander Nechaev, Russia Focuses on IPR. Fight Against Piracy, TASS, Apr. 23, 1997, available in LEXIS, Europe Library, Tass File.

138. "[T] he Russian government, to their credit, have begun some enforcement actions." Remarks by USTR Jeffrey Lang, supra note 6. 
a total of 123 criminal cases against intellectual property pirates were brought in 1996; in 29 widespread mopping-up operations mounted in 17 cities across the nation, police closed down 16 clandestine businesses, seized over 400 pieces of copying equipment, as well as nearly 100,000 compact discs. worth $\$ 3$ million. ${ }^{139}$

The major incentive for these actions is Russia's desire to join the WTO.$^{140}$ In addition, Russia is finally beginning to realize that it is losing revenues from unlicensed goods. Russia estimates that money lost on video counterfeiting alone amounts to $\$ 270$ million a year. ${ }^{141}$ Russia's actions in enforcing its intellectual property laws, even though directed at improving protection of the more tangible copyright and trademark rights, are important for the protection of patent rights as well, because they demonstrate a change in Russia's priorities. Only a year ago, commentators defined enforcement of IP laws as a low priority for Russia. ${ }^{142}$ Now, the Russian government has stated that it intends to deal very intensively with problems of protecting intellectual property. It considers this issue "a priority . . . in the work of the relevant agencies, ministries on the territory of the Russian Federation." ${ }^{143}$ If Russia's intentions to confront IP protection problems directly lead to concrete actions, eventually foreign and Russian companies "will be able to have some confidence in intellectual property protection in Russia." 144

Another positive sign is a decision by the Supreme Court of the Russian Federation allowing judicial review of the administrative decision of Rospatent's Patent Chamber of Appeals. ${ }^{145}$ This decision was a result of the

139. Alexei Grishin, 'Intellectual Pirates' Are Still Running Riot In Russia, BizEKoN NEwS, June 19, 1997, available in LEXIS, Europe Library, SBE File. According to a statement by Microsoft in October 1997, "in the past eight months police have conducted 40 raids in Moscow and seized more than 200,000 pirated CD-rom disks." Hanuska, supra note 8.

140. For reasons for Russia's desire to join the WTO, see supra text accompanying notes 2-3.

141. EU/Russia: "Substantial" Progress on Trade Issues, Claims EU, EuR. REP., Sept. 3, 1997, available in 1997 WL 13046339 . "EE]xperts estimate that no less than 80 percent of all sales in this country are pirated audio, video, software, and data base products, losing it annually at least $\$ 1$ billion, half of which could replenish its treasury." Grishin, supra note 139.

142. See generally Investment Climate in Russia, supra note 14; Grishin, supra note 139; and Kenneth A. Cutshaw, Russian Roulette, 43-JAN FED. LAw. 30, 34 (1996).

143. Press Briefing on Current Activities of RF Government (Official Kremlin international news broadcast, Apr. 15, 1997), available in LEXIS, Europe Library, SBE File.

144. Remarks by USTR Jeffrey Lang, supra note 6.

145. Postanovlenie Prezidiuma, Verkh. Suda RF, 2 Mar. 1994 [Decision of the Presidium 
St. Petersburg City Court's refusal of jurisdiction to the plaintiff Korpachev. Korpachev resorted to the St. Petersburg City Court to challenge the decision of the Patent Chamber of Appeals which affirmed the finding of the Patent Office as to the invalidity of his certificate of authorship. ${ }^{146}$ The St. Petersburg City Court refused jurisdiction because: (1) the law of the former USSR did not allow judicial review of administrative decisions on the validity of certificates of authorship, and (2) the new Patent Law of the Russian Federation required the Supreme Patent Chamber to be the final arbiter in hearing appeals from the Patent Chamber of Appeals. On Korpachev's subsequent appeal, the decision of the St. Petersburg City Court was affirmed. However, the Presidium of the Supreme Court reversed and remanded the case to the St. Petersburg City Court, finding the decisions of the lower courts in conflict with the Constitution, which ensures everyone's right to judicial review of administrative decisions. ${ }^{147}$ The decision of the Presidium of the Supreme Court created a precedent of judicial review of Rospatent decisions. ${ }^{148}$ This is especially important because it mitigates the impact of the Supreme Patent Chamber's absence from the system. ${ }^{149}$

Russia has made definite progress in improving its protection of patent rights. However, problems in this area are still overwhelming. Impediments to U.S. companies doing business in Russia are so serious that the International Intellectual Property Alliance (IIPA) has recommended that the United States Trade Representative (USTR) designate Russia as one of several "priority foreign countries" whose policies or practices are the most harmful to U.S. industries. ${ }^{150}$

of the RF Supreme Court from March 2, 1994], available in MAT.SUDEBN.PRAKT. [Materials of Courts' Decisions] [hereinafter Decision of RF Supreme Court from March of 1994]. Unlike U.S. sources, Russian official sources refer to cases by case numbers or by the date of the court's decision.

146. The Patent Law allows the Supreme Patent Chamber to hear appeals from the Patent Chamber of Appeals. See supra notes 115-18 and accompanying text. However, Korpachev could not appeal to the Supreme Patent Chamber because it has yet to come into existence.

147. Decision of RF Supreme Court from March of 1994, supra note 145.

148. Even though Russia is not a common law country, a precedent created by a decision of the Supreme Court is likely to be followed by lower courts. SERGEEv, supra note 42, at 25. On October 15, 1996, the Highest Arbitration Court of the RF, in its guiding explanation of case No. 225/96, declared that arbitration courts do have jurisdiction to review decisions of the Patent Chamber of Appeals. See Materials from Michael Solton, an American attorney from Stepotoe \& Johnson specializing in U.S./Russian transactions (on file with author).

149. The impossibility of appealing Rospatent's decisions to the Supreme Patent Chamber may be evidence of a lawless society; however, allowing judicial recourse in questions of the patentability and validity of patents does have its drawbacks. V.A. Mesheryakov, Patentnie spori v Rossii: Kto postavit tochku? [Patent Disputes in Russia: Who Will Put an End?], PATENTI I Lizenzil, No. 9, 7, at 11 (1996).

150. U.S. Industries Recommend Greater Scrutiny for Countries Lacking IP Protection, 9 NO. 4 J. PROPRIETARY RTS. 37 (1997). 


\section{B. Contributing to Problems in Patent Rights Protection: The Drawbacks to Russian Legislation}

There are several flaws in Russian patent legislation that contribute to ineffective protection of inventions. A source of major difficulty in enforcing the Patent Law is the absence of the Supreme Patent Chamber to which the law assigns several important functions. ${ }^{151}$ One of its functions is to review decisions of the Patent Chamber of Appeals. Since appeals from the Patent Office to the Patent Chamber of Appeals are reviewed by the same individuals, ${ }^{152}$ it is unlikely that an unfavorable initial decision will ever be reversed. After the Korpachev ruling of the Supreme Court of the Russian Federation, ${ }^{153}$ one can resort to judicial review of Rospatent decisions. Unfortunately, the courts' competency in such disputes is questionable. Furthermore, V.A. Mesheryakov, the chairman of the Patent Chamber of Appeals, said that the right to judicial review of Rospatent decisions was allowed for reasons of expediency, rather than for legal reasons. ${ }^{154}$ In addition to reviewing Rospatent decisions, there are other functions assigned to the Supreme Patent Chamber. The law mandates that the Chamber resolve disputes arising over non-exclusive compulsory licenses, over open licenses, and over patented inventions used upon permit from the government, but without consent of the patent owner. ${ }^{155}$ Parties to such disputes are currently left without remedy, since these disputes are under the exclusive jurisdiction of the Supreme Patent Chamber, which has not yet been established.

Another shortcoming of the Patent Law is that some of its provisions are so broad and unclear that their interpretation can lead to an unpredictable result. Article $10(5)$ is one example of such ambiguity. ${ }^{156}$ Moreover, in granting rights of "further gratuitous use" to prior users of an invention,

151. The President of the RF, in his edict from September 11, 1997, requested the formation of the Chamber. Subsequently, on September 19, 1997, the RF Government promulgated a decree which ordered Rospatent to present a proposal on the formation of an entity carrying out the functions of the Chamber within three months. See supra text accompanying notes 112-13. However, currently the Chamber still does not exist and no exact date has been set for its creation.

152. Cynthia Vuille Stewart, Trademarks in Russia: Making and Protecting Your Mark, 5 TEX. INTELL. PROP. L.J. 1, 14 (1996). The appellate procedure in Rospatent is similar to the procedure that existed under the Soviet system. See supra notes 34-38 and accompanying text.

153. For details on the Korpachev ruling, see supra text accompanying notes $145-47$. Despite this ruling, courts may still refuse jurisdiction over these disputes: "functions [of the Supreme Patent Chamber] are sometimes performed by courts, but there is no common practice on this point." Christophoroff, supra note 90.

154. Mesheryakov, supra note 149 , at 11 .

155. See supra text accompanying notes 119-21.

156. See supra text accompanying notes 76-77. 
Article 12 uses the terms "scope," "necessary preparations," and "identical solution" without providing any guidance to courts on how to interpret those terms. ${ }^{157}$ Article 10(4), in using the terms "inadequate use" and "sufficient excuse" to describe the actions of a patent owner, gives the Supreme Patent Chamber too much discretion in making its decision on granting a nonexclusive license. ${ }^{158}$

In addition to using ambiguous terms, the existing legislation fails to cover some aspects of patent rights protection. For example, despite its title- "Protection of Rights of Patent Owners and Inventors"-Part VII of the Patent Law includes only two articles, neither of which provides assistance to courts in the adjudication of patent owners' and inventors' disputes. ${ }^{159}$ Article 31 simply contains a list of potential patent disputes which can be resolved by the courts. Article 32 states that usurping inventorship or making unauthorized disclosure will result in criminal liability; however, in practice, such liability rarely attaches. ${ }^{160}$ The law fails to define concrete methods of protection for patent owners' rights. It neither addresses the issue of liability, nor specifies sanctions that can be used by courts. The legislation does not provide any direction for calculating damages in patent infringement cases-a task which has proven to be a source of great difficulty for courts in adjudicating such cases. ${ }^{161}$

Finally, as part of the new Criminal Code, which imposes criminal liability when an infringer causes "significant damages," the term "significant damages" has made many law practitioners unhappy. Aware that "the courts will be hesitant to make such an interpretation, "162 they want clarification of this terminology. Practitioners also suggest that targeting only repeat offenders, conspirators, organized crime rings, and those offenders who cause "significant damages," renders the measures of the new Criminal Code "too mild to serve as an effective deterrent for infringers." 163

157. See supra text accompanying notes 78-79.

158. See supra notes $73-75$ and accompanying text.

159. A law professor at the St. Petersburg State University, A. P. Sergeev, calls Part VII "the most weak and incomplete part of the Patent Law." SERGEEV, supra note 42, at 165.

160. Id.

161. GoRlenKo ET AL., supra note 123 , at 200 . Article $14(2)$ is the only place where remedies are briefly mentioned: "On [the] patentholder's demand, infringement of [the] patent must be ceased, and [the] natural or legal person infringing [the] patent shall have the duty, in conformity with RF civil legislation, to indemnify [the] patentholder for the losses caused." Patent Law, supra note 44 (art. 14(2)).

162. Russia Steps Up Enforcement of Intellectual Property Rights, Russ. \& COMMONWEALTH BUS. L. REP., July 29, 1996, available in LEXIS, Europe Library, SBE File (citing Eugene Arievich, a partner in the Moscow office of Baker \& McKenzie). Irina Savelyeva of Lex International has noted with disappointment that the requirement for damages to be "significant" creates "a burden of proof that does not exist in Western law." Id.

163. Solton, supra note 18. 


\section{Practical Problems in Protecting Patent Rights in Russia}

Protection of patent rights in Russia is one of the major concerns of western companies when they consider investing in Russia. In the meantime, this issue continues to generate complaints from western companies that are already located in Russia. It is the main obstacle to Russia's accession to the WTO. Inadequate protection of patent rights is also hurting domestic companies and discouraging development of innovations within the country. Russia is losing millions of dollars in revenues from unlicensed goods and from its failure to patent inventions abroad. Despite some positive changes, serious problems with the protection of patent rights still exist and continue "to present major problems for both Russian and foreign companies with negative implications for Russian consumers." 164

\section{Inadequate Enforcement of the Existing Legislation}

Among other problems, most critical is the inadequate enforcement of the existing law. ${ }^{165}$ The judicial system in Russia is incapable of resolving complex patent disputes. ${ }^{166}$ One of the reasons for this is a lack of experience. For example, the City Court in St. Petersburg, a city with a population of over five million people and a great potential for innovations, adjudicates less than ten patent disputes annually. ${ }^{167}$ Such a low number of patent disputes has a historical explanation. In the former Soviet Union, where patent protection was essentially non-existent, patent infringement disputes could not even arise. ${ }^{168}$ A majority of other kinds of patent disputes were not within the courts' jurisdiction and had to be decided by administrative organs. ${ }^{169}$ The lack of skilled attorneys and their unwillingness to take such cases also contributed to the dearth of judicial decisions regarding patent disputes. ${ }^{170}$ Furthermore, courts refrained from

164. West's Legal News Staff, Conference Calls for Russia to Take Immediate Steps for IP Protection, WeSt's Legal News, Feb. 15, 1996, available in 1996 WL 258540 [hereinafter Conference on IP Protection].

165. According to John Romary of Finnegan Henderson Farabow Garrett \& Dunner, a Washington-based law firm that specializes in patents, "although in theory Russian law provides world-class protection of IPR according to their terms and conditions, he doubts the practical enforceability of IPR in the Russian Federation." Pamela Pohling-Brown, Contracting Issues: International Property Rights Require International Reform, JANE's DEF. CONT., Sept. 1, 1997, available in 1997 WL 9097513.

166. Solton; supra note 18; SERGEEV, supra note 42, at 26; Conference on IP Protection, supra note 164; Stewart, supra note 152, at 16.

167. SERGEEV, supra note 42 , at 26.

168. See supra Part II.A.

169. See supra notes $40-41$ and accompanying text.

170. SERGEEV, supra note 42 , at 26 . Attorney's fees in patent cases were significantly 
adjudicating patent cases because the amount of compensation awarded to inventors was usually low (much less than judicial expenses), although the lawsuits themselves were complex and lengthy and required judges to delve into scientific and technical issues. ${ }^{171}$

Unfortunately, this situation has not changed. Parties are still reluctant to bring legal actions. Unlike western countries, Russia has no courts specializing in patent disputes. ${ }^{172}$ Patent disputes are resolved by civil courts and arbitration courts that suffer from case overload and a lack of expertise in questions involving the protection of patent rights. The judges lack training and experience in the adjudication of patent law issues, which involve complex technical and scientific matters. The poor record of judicial enforcement also has its roots in judges' reputations for taking bribes ${ }^{173}$ and for ignoring the existing laws and decisions of higher courts. ${ }^{174}$ The resources allocated to the judicial system are extremely limited. ${ }^{175}$ Foreign firms that have brought lawsuits in Russia complain about the impossibility of predicting an outcome, the slow and expensive court actions, and the low fines. ${ }^{176}$ Furthermore, Russian patent law specialists complain that the existing courts are inadequate to adjudicate patent disputes. ${ }^{17}$ Often the only

lower than the fees for civil and criminal cases because of the limited financial abilities of inventors. Id. at 164.

171. Id. Only 200 lawsuits related to inventions were filed annually in the courts of general jurisdiction in the former USSR; arbitration courts did not adjudicate such cases at all. GORLENKO ET AL., supra note 123, at 195.

172. The United States CAFC and the German Federal Patent Court both specialize in patent disputes. See infra notes 260-63 and accompanying text.

173. Stewart, supra note 152 , at 16 . The parties' faith in a fair outcome is reduced by "the traditionally low level of societal respect for the judicial branch of government." Id.

174. Alexei Renkel, Izobretatel' $v$ sudebnikh jernovakh [An Inventor in a Judicial Grindstone], ZAKON, No. 2, Feb. 1997, available in KODEX. Vladimir Shitikov of Soyuzpatent gives the example of the case between the patent owner, an enterprise, and the authors of the invention patented abroad where the judge repeatedly ignored opinions of the higher courts, including the opinion of the Supreme Court of the RF. Vladimir Shitikov, Delo ne $v$ zakone, a vtom, chtobi on rabotal [The Cause is not the Law but its Enforcement], ZAKON, No. 2, Feb. 1997, available in KODEX.

175. Solton, supra note 18. Judges become "an endangered species, as their jobs grow increasingly more complex and more dangerous-without a corresponding raise in pay." Suzanne Possehl, New Crime and Punishment, 82-Nov. A.B.A. J. 72, 75 (1996).

176. Stewart, supra note 152 , at 16.

177. Alexei Renkel gives an example of a case involving a dispute between the inventor, Kriman, and his employer, NPO Ekran. Renkel, supra note 174. In 1989, Kriman designed an incubator for premature babies. The enterprise Ekran, Kriman's employer, refused to apply for certificates of authorship for inventions included in the design of the incubator, because Kriman did not add the Chief Engineer as an author of the inventions. Kriman himself applied for two certificates and informed directors of Ekran that he received the certificates and that the design included other patentable inventions. Ekran neither disputed Kriman's rights to the certificates, nor attempted to patent other inventions. As a result, from 1989 to 1994, Kriman himself obtained three more patents for two inventions and one 
possible explanation that can be given for a court's actions at trial is that the court had decided the case beforehand. ${ }^{178}$ Such actions by the Russian courts destroy the faith of future litigants in a fair outcome and discourage them from bringing suits to protect their patent rights.

It is noteworthy that some representatives of the Rospatent administration think that the Russian judicial system is capable of providing adequate protection of patent rights. ${ }^{179}$ However, the low number of patent disputes resolved by the Russian courts suggests the contrary. B.A. Lobach of Rospatent, in his articles in Ekonomika I Jizn' [Economy and Life] and Patenti I Lizenzii [Patents and Licenses], tried to come up with an optimistic conclusion about the courts' ability to provide adequate protection of patent rights by relying on the courts' decisions in two patent disputes. ${ }^{180}$ One may

industrial design. In 1992, Ekran began producing incubators. Kriman offered Ekran the opportunity to buy a license for the use of Kriman's patents. Ekran refused, and in 1995 Kriman filed a lawsuit in the Nagatinskii District Court, which held for the defendant. The Moscow City Court affirmed the decision. Both courts ignored the fact that the inventions were originally protected by certificates of authorship in accordance with the old Soviet law and instead applied the new Patent Law of the RF. In addition, the Moscow City Court, citing the right of prior use in justifying its decision, never requested the defendant, who should have had the burden of proof, to prove that it had such a right. The court refused to admit the deposition of Ekran's patent specialist, stating that applications for four inventions were drafted at Ekran and were filed by Kriman himself merely because Kriman refused to include the Chief Engineer as an author. Moreover, not only did the court hold that Ekran had a right to use Kriman's patents without a license, it awarded no compensation to Kriman for Ekran's use of Kriman's patents. Id.

178. Renkel, supra note 174. Another case described by Alexei Renkel involved a decision of the Lefortofskii District Court (Moscow) in April 1996 on the infringement of the plaintiff's invention by the foreign company Rank Xerox. The court allowed the defendant first to dispute the validity of the patent in question, and then to claim that its Moscow office was not a legal entity, thereby sheltering Rank Xerox from responsibility for its actions. However, the court did not even require Rank Xerox to explain the presence of the Rank Xerox office in Moscow and how thousands of its goods have crossed the customs control of the Russian Federation. The testimony of the experts used by the court clearly demonstrated their bias for the defendant, but the court simply ignored the plaintiff's claim of expert partiality and decided for the defendant. The Moscow City Court affirmed the decision. Id.

179. Lobach I, supra note 131, at 13; B. Lobach, Kontrafaktnaya produkziya - eto vsegda sankzii [Counterfeit Products Always Lead to Sanctions], EKON. I ZH., No. 26 (1996), available in KODEX [hereinafter Lobach II].

180. In the first case, the Jeleznogorsk City Court, on March 16, 1995, found the local company, Kristall, liable for infringing the plaintiffs' patent. In calculating damages, the court took into account the intentional character of defendant's infringement, since Kristall had ignored the plaintiffs' offer to enter into a licensing agreement and continued to produce counterfeit products even after the plaintiffs filed a lawsuit. On appeal, the Kursk Regional Court affirmed. The second case, which was decided by the Savelorskii Municipal Court of Moscow in the summer of 1995, involved unintentional infringement of plaintiffs' patent rights by $\mathrm{AO}$ Eliz. The court encountered numerous difficulties because of its lack of experience in adjudicating similar disputes and because of the defendant's attempts to delay the trial. However, the court, to its credit, was able to determine the fact of infringement and calculate 
consider these two decisions to be encouraging, but certainly they are not enough to overcome the negative stereotype of Russian courts that people have harbored in their minds for many years. In addition, the third case used by B.A. Lobach to support his conclusion that the courts are able to enforce patent owners' rights has been in litigation since 1993, but has not yet been decided. ${ }^{181}$ The four-year litigation of a patent dispute is not a sign of adequate protection of patent rights, especially considering the limited life of patents. Moreover, the decisions that B.A. Lobach relies upon were neither independently published in a legal journal, nor contained in any legal database, thereby diminishing the positive impact of these decisions on potential litigants. ${ }^{182}$ Relatedly, the lack of a comprehensive legal journal with published court decisions presents a further impediment to future parties by depriving them of any indication of their chances in court. ${ }^{183}$

Problems with the judicial enforcement of patent rights have led to further non-use of the Russian legal system by patent owners. ${ }^{184}$ Thus, no judicial precedent has developed to interpret the existing laws and establish the legal climate in the patent law area. ${ }^{185}$ Although the reluctance of patent owners to resort to the courts for the protection of their rights is understandable, it nonetheless compounds the problem, since without practice Russian judges are unlikely to develop expertise in adjudicating patent law disputes. ${ }^{186}$

Another practical problem hindering the effective enforcement of patent rights is corruption and organized crime. CIA Director John Deutch told the U.S. House of Representatives that although calling Russia a lawless state is going too far, organized crime and corruption pose an increasing

damages in light of the unintentional character of defendant's actions. Lobach $\mathbf{I}$, supra note 131, at 12-13; Lobach II, supra note 179.

181. The defendant in this fairly straightforward infringement case is the Moscow office of the Japanese firm Shimadzu Corporation. A delay in the trial was caused by the refusal of the defendant to appear in court based on the argument that its Moscow office is not a legal entity. Lobach II, supra note 179 . It seems that the court should have found a way to address the defendant's argument. See Renkel, supra note 174, for Alexei Renkel's comments on a similar case against Rank Xerox.

182. Russian legal databases contain only decisions of the Supreme Court of the RF.

183. Stewart, supra note 152 , at 16.

184. Id. "Ironically, many IP owners themselves are, in a sense, contributing to the perpetuation of the enforcement vacuum that is so detrimental to their business in Russia." Solton, supra note 18.

185. Stewart, supra note 152 , at 16.

186. Solton, supra note 18. Vladimir Shitikov of Soyuzpatent says that some blame for inadequate protection of patent rights in Russia should be borne by foreign firms because of their failure to prosecute infringers. He explains that even the most progressive law is inefficient when the victim has no desire to protect his or her own rights. Shitikov, supra note 174. 
threat to its political and economic stability. ${ }^{187}$ A feeling of helplessness caused by corruption and organized crime discourages patent owners from actively pursuing enforcement of the law and destroys their belief in the existence of fairness in Russia.

Finally, the misunderstanding of basic patent law concepts among the vast majority of the Russian population, including its most educated citizens, causes a serious impediment to effective protection of patent rights. ${ }^{188}$ During the seventy-five years preceding the first Russian Patent Law, the Soviet legal system neither recognized nor protected rights of inventors. Instead, the notion was that a discovery or creation, made for the good of the entire country, was owned by all the people and had to be disseminated to a "wider sector of the population rather than to curtail undue competition and protect the individual rights of creators." 189 The five years following the adoption of the new Patent Law were not enough to change this ideology. As a result, local companies and even judges often do not realize that the use of an invention created by another without permission is theft. ${ }^{190}$ The Russian government, wanting to join the WTO, has been forced to recognize that the protection of intellectual property rights in Russia needs improvement. Still, Russia has failed to make IP protection a highest priority, perhaps because the government does not realize the importance of IP protection in achieving Russia's major tasks of economic and social stabilization. ${ }^{191}$

\section{Problems with Inventions Predating the Patent Law of the Russian Federation}

One of the problems in providing adequate protection of patent rights is the uncertainty of ownership with respect to inventions predating current legislation. Certificates of authorship issued in the former Soviet Union still remain in effect, and unless the certificates have been exchanged for patents, the inventions protected by them may be freely utilized by any company. ${ }^{192}$

187. Possehl, supra note 175 , at 79. "Extortion, government corruption, organized crime ... are now thriving in the absence of a firmly entrenched legal system, " id. at 72 , which forces companies to pursue other means in protecting their rights "ranging from manipulation of the political system to use of less desirable means of coercion." Stewart, supra note 152 , at 16.

188. Solton, supra note 18.

189. Baev, supra note 12 , at 364 . For more on protecting inventions under the Soviet system, see supra Part II.A.

190. SERGEEV, supra note 42, at 165 . See also Solton, supra note 18.

191. Baev, supra note 12 , at 365 .

192. See supra note 93 and accompanying text. The law requires payment of compensation to the holder of the certificate. See supra notes $94-98$ and accompanying text. However, in practice, they can be "utilized by the state or any private company without 
Thus, when a foreign or Russian company decides to use an invention protected by a certificate of authorship, it takes the risk to find that, after significant spending on preparation, it may not be the sole user of this invention in the market.

In addition, it is unclear who holds the patent rights to inventions formerly owned by state enterprises and research and development institutes that have been recently privatized. ${ }^{193}$ Since state-owned enterprises do not have exclusive rights to inventions protected by certificates of authorship, the inventions cannot be practically transferred to the new company during the process of privatization. Therefore, a foreign company planning "to export a Russian technology that promises to provide a handsome income" has to be aware that any private or state entity, or the government itself, may claim a property right to an invention protected by a certificate of authorship. ${ }^{194}$ Moreover, if a privatized company wants to assert rights to its inventions, an infringer may be able to contest the claim of infringement on the basis that the privatization process was not conducted properly with respect to intellectual property rights. ${ }^{195}$

Overlap of the old Soviet law and the new Russian law presents a further impediment to those who want to protect their inventions in Russia. For example, under the current law a person or entity using a patented invention without a license is an infringer and is subject to civil and criminal liabilities. ${ }^{196}$ By contrast, the old law allowed the use of a patented invention without a license: since only foreign inventions had patent protection, the law wanted to protect Soviet enterprises from foreign companies who were using a similar invention on the Soviet market. ${ }^{197}$ Today, when a dispute involves an invention predating the existing legislation, it is unclear which law should be applied. ${ }^{198}$ The inconsistencies between the old law and the

compensation." Baev, supra note 12, at 369.

193. Baev, supra note 12 , at 369 . Analysis of the process of privatization in Russia demonstrated that issues of ownership regarding these inventions were not resolved during privatization of state-owned enterprises. B. Maksimov \& V. Sesekin, Voprosi regulirovaniya imusheztvennikh otnoshenii, svyazannikh s ob'ektami okhranyaemoi intellektual'noi sobstvennosti, voznikayushie v prozesse privatizazii [Questions on Regulating Ownership of Intellectual Property Arising in Respect to the Process of Privatization], KHOZ. I PRAVO, No. 10, at 121 (1995).

194. Baev, supra note 12 , at 370 . The government may do it to "protect national strategic interests, obstruct suspicious projects, or bargain with large foreign investors." Id.

195. Id. It will be easy to contest the claim on this basis because the intellectual property rights are not usually clarified in the charter or privatization plan of the privatized company. Id.

196. E. Danilina, Zashita prav, vitekayushikh iz patenta, na docydebnom etope [Pre-Trial Protection of Patent Rights], INTELlekTUAL'NAYA SOBSTVEnNOST', No. 7-8, at 78 (1997). See also Patent Law, supra note 44 (art. 14).

197. Danilina, supra note 196 , at 76.

198. Id. 
current legislation create uncertainty with respect to the ownership of patent rights, thereby impeding the protection of patent rights in the country.

Another practical problem results from the economic conditions in Russia. Rapid inflation makes it very hard for the patent owner to estimate the actual amount of damages that may be received. ${ }^{199}$ The Moscow City Court, in a decision dated January 21, 1993, awarded the plaintiff Prohorenko 3240 rubles as compensation for the use of his invention by the factory Metallist. ${ }^{200}$ The plaintiff requested the court to recalculate the amount of damages due to inflation. ${ }^{201}$ On July 5, 1994, the court increased the award to 526,437 rubles, in accordance with the inflation rate in January 1993. The Supreme Court left this amount unchanged, although the plaintiff argued that the Moscow City Court should have relied on the inflation rate as of July 1994 and awarded him 2,896,041 rubles instead. ${ }^{202}$ Thus, by the time the plaintiff received the compensation, its actual value had dropped by more than $500 \%$.

\section{Failure to Protect Russian Inventions Abroad}

Russian inventors not only lack adequate patent protection for their inventions in Russia, but their inventions rarely receive protection abroad. Only 100 to 150 patents have been obtained abroad annually during the years of economic reform, compared to 2450 patents received in $1988 .{ }^{203}$ The main reason for this is that inventors themselves now have to pay for obtaining patents abroad. In the former Soviet Union, the state incurred all

199. For example, the inflation rate in Russia was $21.8 \%$ in 1996 , more than $130 \%$ in 1995, and much higher in the previous three years of economic reforms. Russian 1996 Inflation, UNITED PRESS INT'L, Jan. 6, 1997 (visited Nov. 8, 1997) < http://www.nd. edu/ astrouni/zhiwriter/97/97010803.htm >.

200. Opredelenie Sudebnoi kollegii po grajdanskim delam, Verkh. Suda RF, 24 Aug. 1994 [Decision of the Judicial Board on Civil Cases of the Supreme Court of RF from August 24, 1994], available in MAT.SUDEBN.PRAKT. [Materials of Courts' Decisions].

201. In calculating the amount of damages, the Moscow City Court properly applied the statute effective at the time the defendant began to use the invention but failed to increase the amount in accordance with the rate of inflation. Id.

202. The Supreme Court reasoned that the proper rate is the rate existing at the time the trial court initially awarded compensation to the plaintiff. Id.

203. A. Kolesnikov \& L. Tolchkova, Sostoyanie rinka otechestvennikh tekhnologii [The State of the Market of Native Technologies], INTELLEKTUAL'NAYA SOBSTVENNOST', No. 1112, at 13 (1996) [hereinafter Current State of Native Technologies]. Expenses related to patenting abroad currently exceed native patenting by 3-5 times. Id. Inventions in the former USSR were covered "in more than 50 countries of the world with the total number of patented technologies estimated at 40,000." Irina Skibinskaya, High-Tech Exports Are To Be Covered By Patents To Avoid Losses, BIzEKon NEws, Sept. 29, 1997, available in 1997 WL 7802816 [hereinafter Skibinskaya, Sept. 1997]. 
expenses related to patenting Soviet inventions abroad. ${ }^{204}$ Today, Russian inventors lack the money to patent inventions themselves and are denied governmental assistance. ${ }^{205}$ In addition, there is little understanding of the value of patenting abroad. Russian inventors, including the government, are not accustomed to considering inventions as a source of revenue. As a result, Russia is losing millions of dollars by selling high-tech items abroad without patenting each of their elements. ${ }^{206}$ One recent example involved the sale of twenty-nine MIG warplanes to Malaysia by one of the former vicepremiers. Since some of the technologies involved were not patented abroad, the buyer completely dismantled one of the MIGs and copied it outside of Russia without paying any patent fee whatsoever. ${ }^{207}$ Another example involved an exhibit in the United States which was mounted by "a reputed domestic industrialist ... without bothering to gain patenting safeguards. "208 The result was that most of the displayed innovations "were just pilfered, as admitted by the hosts themselves, and such instances are aplenty. "209 Lack of adequate protection of Russian inventions abroad is also the source of Russia's serious concern regarding the execution of an agreement to export Russian machinery to China. ${ }^{210}$ While the value of Russian exports to China is expected to reach $\$ 20$ billion by the year 2000 , only eight patent applications were filed by Russia in the Chinese Patent Office in 1994, compared to 3461 patent applications filed by Japan and 2178 applications filed by the United States. ${ }^{211}$ Russia's failure to protect its inventions abroad has impeded the development of innovations in the country and has led to Russia's inability to influence relevant foreign markets, gain

204. Current State of Native Technologies, supra note 203. Another reason for a decrease in the number of patents obtained abroad is a lower number of inventions created in Russia in general. Sergei Zhiltsov, Government To Address Venture Capital Problems, BizEKoN NEws, Aug. 14, 1997, available in LEXIS, Intlaw Library, Russica File. For more information on problems with innovations in Russia, see Nataliya Davydova, New Technologies Bank On Small Business, BIzExon NEws, Aug. 14, 1997, available in LEXIS, Intlaw Library, Russica File; and Russia: Development of the Intellectual Property Market in Russia is in Progress, DELOVOI MIR, Aug. 22, 1997, available in 1997 WL 14053905 [hereinafter IP Market in Russia].

205. Irina Skibinskaya, Licenses Are More Profitable To Sell Abroad Than Diamonds, BIzEKoN NEwS, Mar. 26, 1997, available in 1997 WL 7801643 [hereinafter Skibinskaya, Mar. 1997]. Patenting abroad used to be a significant source of Russia's profits: “in 1993, for instance, such profits amounted to USD $\mathbf{4 0 0}$ million." Id.

206. Id.

207. Skibinskaya, Sept. 1997, supra note 203.

208. Skibinskaya, Mar. 1997, supra note 205.

209. Id.

210. V. Evdokimova \& V. Blinnikov, Rossiya-Kitai: pravovaya zashita intellektual'noi sabstvennosti [Russia-China: Protection of Intellectual Property], EkoN. I ZH., No. 27, at 20 (1996), available in CONSULTANTPLUS.

211. Id. 
profits from the sale of licenses, and receive the advantages of exporting its goods and technologies. ${ }^{212}$

\section{RECOMMENDATIONS FOR IMPROVING PROTECTION OF PATENT RIgHTS IN RUSSIA}

\section{A. Using Means Available Today: Recommendations to Patent Owners}

While waiting for radical governmental improvements in the protection of patent rights, patent owners-whether they are individuals or foreign or domestic private firms-should take action themselves to protect their rights. Aggressive action by private owners will deter infringers, bring to light the most serious problems in patent protection, and help to eliminate those problems.

Since the resolution of patent disputes in courts is problematic, a patent owner needs to exhaust all possible alternatives before bringing a lawsuit. ${ }^{213}$ In the making of a license agreement, contractual safeguards may be used to avoid future disputes should patent misuse occur. ${ }^{214}$ To protect their interests, patent owners should include provisions depriving the licensee of all rights granted by the license if the licensee misuses the patent in any way. An effective agreement will also make the licensee accountable for significant liquidated damages (which are now enforceable under Russian contract law) for violations of the licensing agreement. ${ }^{215}$ Such provisions will deter the licensee from possible wrongdoing and shift the court's review from complex patent law issues to more familiar contract law issues if the misuse nonetheless occurs. In addition, the parties can "include an international arbitration clause or choice of law provision indicating foreign law" in order to avoid placing themselves into the unpredictable hands of the Russian judiciary. ${ }^{216}$

212. Russia's failure to patent its inventions abroad is especially unwise since it "has a vastly untapped renewable resource to offer the world as yet." Georgi Osipov, A Man Who Masterminded VAZ, BIZEKON NEWS, May 29, 1997, available in 1997 WL 7802107. At a recent international show in Brussels, all of the 227 displayed Russian inventions received awards, including Grand Prix for a man-made cardiac valve. Id.

213. B.A. Lobach recommends resorting to nonjudicial means of patent protection for an additional reason: if the plaintiff fails to demonstrate to the court that the resolution of the dispute was impossible without judicial intervention, the plaintiff loses its claim in any arbitration court. GORLENKO ET AL., supra note 123, at 196.

214. Stewart, supra note 152 , at 24 (recommendations to trademark owners which are applicable to patent owners as well).

215. Id. (citing GK RF art. 330, translated in RUSSIA AND THE REPUBLICS LEGAL Materials, No. 33, 160 (John N. Hanland \& Vratislan Pechota eds., 1996)).

216. Id. "However, companies should be aware that even the successful use of arbitration may not adequately address enforcement deficiencies." Id. (citing U.S. Council for 
In case of infringement, the patent owner has two options to consider before filing a lawsuit. The patent owner should first make an attempt to peacefully coexist with the infringer on the market. ${ }^{217}$ A mutually profitable licensing agreement with provisions protecting the invention from other infringers may be the most feasible way to eliminate the conflict, thereby benefitting both the licensor and the licensee and avoiding expensive and lengthy litigation in the unpredictable legal climate of contemporary Russia. The second option for the patent owner would be to force the infringer to stop using the patent. Warnings, letters threatening to bring a lawsuit, publications in the press, and other means of self-help seem to be the safest, easiest, and most inexpensive ways for patent owners to protect their rights. ${ }^{218}$ According to Michael Solton of Steptoe \& Johnson in Washington, D.C., these methods are usually chosen by U.S. companies faced with violation of their IP rights in Russia and have proven to be effective in some situations. $^{219}$

When self-help does not work, a victim of infringement still has another option before resorting to a court's assistance: an unfair competition claim may be filed with the Anti-Monopoly Committee (AMC), which is an administrative organ existing in every region of the Russian Federation. 220 With respect to inventions, any use of scientific, technical or industrial information without the owner's consent, as well as any violation of standards of good faith or the encroachment upon industrial property rights, constitute unfair competition. ${ }^{21}$ AMC proceedings can provide an effective means for patent owners to protect their patent rights for several reasons. First, the AMC proceedings are well-defined, inexpensive, fast, and closed to the public, which reduces the risk of disclosure of confidential information. ${ }^{22}$ Second, the AMC has its own enforcement mechanisms: it

International Business, Intellectual Property Committee Working Group on Central Eastern Europe/CIS, at 2 (General Discussion Points for Meeting with USTR Officials Regarding IPR Enforcement in Russia) (Mar. 15, 1996) (unpublished manuscript on file with the Texas Intellectual Property Law Journal)).

217. Danilina finds from her legal practice that such an option is the best possible solution. Danilina, supra note 196 , at 79.

218. Id.

219. Private Communications with Michael Solton (on file with author) [hereinafter Solton Communications].

220. Danilina, supra note 196, at 79; Solton, supra note 18; Stewart, supra note 152 , at 25 .

221. Danilina, supra note 196 , at 79 . See also supra text accompanying notes 106-07. An unfair competition claim can be filed by any federal or local government agency or any foreign or local business entity; the AMC itself can also initiate such a claim. Solton, supra note 18. AMC does not protect patent rights if no proof of unfair trade practices exists, even when a clear violation of patent rights may be evident. Id.

222. Solton, supra note 18. "As of January 1, 1996, total AMC fees were 50 minimum monthly wages, or approximately $\$ 700$. $^{n}$ Id. It takes one month for AMC to determine 
may grant injunctive relief, impose severe administrative fines, or file civil and criminal charges against the infringer. ${ }^{223}$ Third, administrative enforcement mechanisms in Russia are more developed and have proved to be more efficient than judicial enforcement. ${ }^{224}$ Fourth, AMC proceedings do not bar subsequent or concurrent legal action. ${ }^{225}$ Finally, a "favorable final AMC decision may serve as a deterrent for other existing and potential infringers of petitioner's IP rights or as a precedent in any subsequent AMC proceedings involving the similar rights. "226 Thus, the AMC proceedings can effectively protect patent owners when the infringer's actions constitute unfair trade practices.

When all other alternatives have been exhausted, the patent owner should not ignore the availability of recourse to the courts. Although the Russian judicial system is far from flawless, the patent owner still should seek recourse in the courts instead of passively waiting until IP protection changes in Russia. Russian patent law specialists are unanimous in their insistence that the new Patent Law provides adequate protection of patent rights and that patent owners should pursue their claims in courts to avail themselves of remedies provided by the law and to punish wrongdoers. ${ }^{227}$ To increase the possibility of getting a court's favorable decision, though, the patent owner, before bringing suit, needs to be well-prepared for trial. Thorough preparation for trial requires that a plaintiff secure three specific categories of proof. First, the patent owner must establish that the alleged infringer is using exactly the same invention claimed in the patent, or else the use will not be considered an infringement. Additionally, the patent owner should have evidence of its lost profits and harm to its business reputation in order to lay grounds for the court's award of damages. For a more effective

whether alleged anti-competitive practices exist (though sometimes it may be extended to three months), and another three months to complete the proceeding if AMC determines that a violation is likely to exist (though the completion of the proceeding may be extended up to six additional months). Id. Thus, the proceedings will never take more than twelve months.

223. Danilina, supra note 196 , at 79 . Fines imposed on the infringer range up to 25,000 minimum monthly wages, or approximately $\$ 380,000$; fines imposed on the infringer's officers and directors, in their individual capacities, can reach as high as 200 minimum monthly wages, or approximately $\$ 30,000$. Solton, supra note 18 . In addition, AMC “can freeze bank accounts, seize goods, and compel the payment of fines up to 5,000 minimum monthly salaries." Stewart, supra note 152 , at 25 .

224. Solton, supra note 18.

225. Id. Where a party appeals an AMC's decision in court, enforcement of the AMC decision is suspended until the court rules on the appeal. Id.

226. Id. A favorable AMC decision can be used as evidence in a subsequent civil or criminal trial. Id.

227. See generally Lobach I, supra note 131, at 13; Shitikov, supra note 174; Danilina, supra note 196, at 80; V. Trushina, Izobretatel' pobedivshii zavod [The Inventor Winning the Factory], INTELLEKTUAL'NAYA SOBSTVENNOST', No. 3-4, at 56 (1996). 
trial, it is also helpful to produce a sample of the counterfeit product. ${ }^{228}$ Another important threshold concern for plaintiffs is the choice of forum. B.A. Lobach recommends that the patent owner seek to have a higher court (such as a regional court) adjudicate the dispute in the first instance in order to receive a more skilled review of the claim. ${ }^{229}$ The active use of judicial enforcement by patent owners will lead to the refinement of patent legislation and, more importantly, will help Russian judges to develop expertise in the adjudication of patent disputes. ${ }^{230}$

Patent owners can also promote their interests by influencing legislative changes in Russia. In October of 1997, trademark holders launched the Association of Trademark Owners, which advocates protection of trademark rights against "rampant trademark infringement" in the country. ${ }^{231}$ Gene Arievich, of the Moscow firm of Baker \& McKenzie, believes that such a powerful public organization was much needed "to introduce changes in the laws at the State Duma level . . . [and] to work closely with the Ministry of Interior, State Customs, even the Anti-Monopoly Committee, and make them aware of the issues. ${ }^{232}$ The protection of patent rights is no less necessary today in Russia. The formation of an organization that could join patent owners to lobby its interests to the Russian government would promote stronger patent protection in Russia.

Finally, foreign companies that either enter into licensing agreements with Russian companies or have Russian partners can take several practical steps to protect their patent rights under Russian law. For example, when a foreign company provides a Russian company with the right to use a foreign invention, both the invention and the licensing agreement transferring rights of use to the Russian company should be registered with Rospatent. ${ }^{233}$ Otherwise, the foreign company will not be able to defend its patent rights, and the licensing agreement could be deemed invalid, with the further consequence that the tax authorities would disallow tax deductions for

228. Danilina, supra note 196 , at 80.

229. GORLENKO ET AL., supra note 123, at 195. District courts have little experience in resolving patent disputes since traditionally patent disputes were adjudicated by higher courts. Id. On how to get higher courts to try patent disputes, see supra note 125 .

230. Solton, supra note 18 . "[I]f no one brings suit, Russian judges are unlikely to develop the much needed IP expertise in the near furure." Id.

231. Erin Arvedlund, Trademark Association Founded, Moscow TIMES, Oct. 14, 1997, available in LEXIS, Europe Library, Mostms File.

232. Id. As Arievich notes: "The association will lobby the government via . . . Rospatent." Id.

233. Scott Antel \& Mikhail Bortnyaev, Intellectual Property: Protecting Your Rights, Moscow TIMES, July 16, 1996, available in LEXIS, Europe Library, Mostms File. The procedure of registering the invention is often "overlooked or ignored." Id. Note that inventions that are well-known worldwide do not need to be registered. Id. 
royalty payments made by the Russian user. ${ }^{234}$

Where foreign companies have Russian partners, they have to be particularly careful in using any of the Russian partners' inventions predating current legislation. If an invention is still protected by a certificate of authorship, the foreign company should insist that its partner exchange the certificate for a patent. ${ }^{235}$ However, the foreign company needs to be aware that exchanging the certificate for a patent does not guarantee the exclusive rights to the invention where the invention was rightfully used by any party at the time the application for a patent was filed. ${ }^{236}$ Moreover, when the Russian partner is a privatized enterprise or a former state research and development institute, the foreign company must verify that the process of privatization was proper and that the patents have been recorded as part of the Russian company's assets. ${ }^{237}$ Because of the uncertainty surrounding ownership of inventions predating the new Patent Law, companies should conduct extensive research before deciding to use such inventions.

\section{B. Radical Changes Necessary to Provide Strong Protection of Patent Rights in Russia: Proposals for Government Actions}

Although private companies must undertake "defensive maneuvers" before they can have confidence in the protection of their patent rights in Russia, a permanent solution to the problems in Russian patent law will be impossible without governmental involvement. ${ }^{238}$ Russia cannot wait until the actions of patent owners slowly lead to improvement of patent protection. Russia must take immediate action since adequate patent protection is vital to Russia's accession to the WTO and to the achievement of "Russia's strategy to attract and maintain foreign investment in the country."239

The first step the Russian government should take is to establish the

234. Id. Recent years have seen "several instances in which tax authorities challenged the validity of deductions for profits tax purposes for unregistered license agreements." Id.

235. Baev, supra note 12, at 369. For more on problems with inventions predating current legislation, see discussion supra Part III.C.2.

236. See Use of Inventions Protected by Certificates of Authorship, supra note 94.

237. Baev, supra note 12 , at $370-71$. Since the IP rights are rarely clarified, companies should "insist that the Russian partner disclose in the joint-venture agreement all its legal rights and obligations" with respect to inventions in its possession; the Russian partner should also assure that it "will remedy all possible legal defects and disputes that might arise." Id. at 371.

238. Stewart, supra note 152 , at 20.

239. The International Conference on the Protection of Trademarks and Patents in Russia, held in Moscow on February 9, 1996, issued a consensus statement requesting the Russian government to take "immediate steps to strengthen intellectual property, trademark and patent protection" in order to join "the World Trade Organization as a full member" and to "achieve Russia's strategy to attract and maintain foreign investment in the country." Conference on IP Protection, supra note 164. 
Supreme Patent Chamber as the Patent Law of the Russian Federation requires. ${ }^{240}$ Although the Patent Law was enacted on September 23, 1992, it was not until September 19, 1997, that the Russian government ordered Rospatent to present a proposal for the formation of the Chamber by December 19, 1997. ${ }^{241}$ As a result, today's administrative system still lacks an effective mechanism by which to appeal Rospatent's decisions on patentability. ${ }^{242}$ The attempts of the Supreme Court and of the Higher Arbitration Court to correct this flaw by allowing recourse to the civil courts did not solve the problem because the civil courts' judges lack expertise in adjudicating patent disputes. ${ }^{243}$ Not only is the Supreme Patent Chamber needed as a venue in which patent owners may appeal decisions of the Patent Office, the establishment of the Chamber is also needed for those parties who have been left without remedy in disputes over which the Supreme Patent Chamber has exclusive jurisdiction. ${ }^{244}$

The most serious obstacle to the importation of foreign technology and investment in the country is Russia's inability to enforce existing patent legislation. ${ }^{245}$ To remove this obstacle, the Russian government must take steps to provide an effective enforcement infrastructure; this can be accomplished only by creating a judicial system capable of addressing complex patent law issues. ${ }^{245}$ The best solution would be to establish specialized patent courts with trained and experienced judges and attorneys. ${ }^{247}$

Although the original version of the Patent Law of the Russian Federation provided for the establishment of specialized patent courts, at the last moment the lawmakers refused to create such courts. ${ }^{248}$ Russian patent law specialists give several reasons for the lawmakers' opposition to the establishment of patent courts. First, the Supreme Court of the Russian

240. Id.

241. See supra text accompanying notes 112-13.

242. See supra notes 151-53 and accompanying text.

243. See supra text accompanying note 153-54. Four trademark cases have been on appeal in the Moscow City Court from the Patent Chamber of Appeals since 1995 and still have not been decided despite the relative simplicity of trademark cases compared to patent disputes. Mesheryakov, supra note 149, at 11.

244. See supra note 155 and accompanying text.

245. Statement on IP Protection, supra note 129. One of three major recommendations given to the Russian Government during the International Conference on the Protection of Trademarks and Patents was to "[e]nforce existing law to stop rampant trademark, patent and copyright infringement." Id.

246. Id.

247. Investment Climate in Russia, supra note 14. This proposal is supported by many patent law specialists. See generally Clamping Down on Russian Piracy, supra note 130; GRISHAEV, supra note 56, at 45-46; Solton Communications, supra note 219; Renkel, supra note 174; and Mesheryakov, supra note 149, at 8-10.

248. GrISHAEV, supra note 56 , at 46. 
Federation was against further division of the Russian judicial system, which already had separated the Constitutional Court and arbitration courts from the courts of general jurisdiction. ${ }^{249}$ Furthermore, the Supreme Court was of the opinion that the courts of general jurisdiction had accumulated enough experience to adjudicate patent disputes. ${ }^{250}$ Second, the need for judges who have technical rather than just legal backgrounds would in turn require new rules of judicial procedure. ${ }^{251}$ Finally, in the opinion of Russian lawmakers, the number of patent disputes is too low to require specialized courts for resolution of such disputes. ${ }^{252}$

None of these reasons, however, withstands scrutiny. First, other countries with separate patent courts consider this specialization advantageous to their legal systems since it provides an effective mechanism to adjudicate patent disputes. ${ }^{253}$ Furthermore, contrary to the belief of the Supreme Court, the five years following the adoption of the new Patent Law have proven that the courts of general jurisdiction have not developed expertise in resolution of patent disputes. ${ }^{254}$ By the same token, having judges with a technical background is so important for the effective adjudication of patent disputes that it would justify changes to the procedural rules in patent courts. ${ }^{255}$ Finally, the low number of patent suits in Russia is more likely a result of the lack of an adequate judicial infrastructure to adjudicate such disputes, rather than a demonstration of a low level of patent infringement in the country. ${ }^{256}$ Alexei Renkel, commenting on the negative attitudes of the Supreme Court and the Ministry of Justice toward the establishment of specialized patent courts, has predicted that if this opposition to patent courts remains, patent disputes in Russia will simply become extinct. ${ }^{257}$

249. Mesheryakov, supra note 149 , at 7.

250. Id. at 8.

251. Id.

252. Renkel, supra note 174.

253. See generally Pegram, supra note 115. In 1981 testimony, Howard T. Markey, then Chief Judge of the Federal Circuit, pointed out an advantage of specialization that would be even more aptly applied to a trial court: "If I am doing brain surgery every day, day in and day out, chances are very good that I will do your brain surgery much quicker, or a number of them, than someone who does brain surgery once every couple of years." Id. at $71 \mathrm{n} .12$ (quoting Court of Appeals for the Federal Circuit: Hearings on H.R. 2405 Before the Subcomm. on Courts, Civil Liberties and the Administration of Justice of the House Comm. on the Judiciary, 97th Cong., 1st Sess. $42-43$ (1981)).

254. See supra notes $166-72$ and accompanying text.

255. Mesheryakov, supra note 149, at 14. The patent court in Germany currently has about 100 judges with technical backgrounds and 50 judges with degrees in jurisprudence. Id.

256. See supra notes $173-75$ and accompanying text.

257. Renkel, supra note 174. 
Examples of patent systems in other major industrial countries demonstrate that patent disputes are more effectively addressed by separate patent courts or by specialized patent divisions of trial courts. ${ }^{258}$ In England, issues of a patent's validity and infringement are brought before the Patents Court, a part of the High Court's Chancery Division, and before the Patents County Court, which was created in 1990 to adjudicate patent disputes between entities of small and medium size. ${ }^{259}$ In Germany, all patent validity disputes are resolved by a special patent court in Munich. ${ }^{260}$ Infringement suits are brought in the federal courts of general jurisdiction, which have a special panel, or "senate," for industrial property infringement cases. ${ }^{261}$ In Japan, although issues of patent validity are within the exclusive jurisdiction of the Patent Office, patent infringement cases are decided by the courts of general jurisdiction, which have special intellectual property sections to adjudicate patent disputes. ${ }^{262}$ In the United States, no patent specialization exists at the trial level, though all patent disputes are resolved by the federal rather than state courts. The United States does provide specialized patent adjudication at the appellate level and requires that all patent appeals be argued before the Court of Appeals for the Federal Circuit. The Federal Circuit has exclusive jurisdiction over district court decisions involving patent issues, as well as over decisions of the Patent and Trademark Office's Board of Patent Appeals. ${ }^{263}$

258. Mesheryakov, supra note 149, at 9; Pegram, supra note 115 , at 71 .

259. Pegram, supra note 115 , at 103-05. Patents Court cases may take up to several years, but if parties agree to a simplified trial, even complex litigation can be completed within a year. Id. at 104. The Patents County Court, created to address concerns over the litigation cost in the Patents Court, has jurisdiction in all of England and Wales with no limitation on amount in controversy or geography. Id. at 104-05. Unlike the Patents Court, the Patents County Court has strict limits on pretrial time and cheaper, speedier and more informal procedures for litigation. Id. at 105.

260. Thomas H. Case \& Scott R. Miller, Note, An Appraisal of the Court of Appeals for the Federal Circuit, 57 S. CAL. L. REv. 301, 333 n.103 (1984) (citing Hearings on S. 677 \& $S$. 678 Before the Subcomm. on Improvements in Judicial Machinery of the Comm. on the Judiciary, 96th Cong., 1st Sess. 478, at 612-13 (1979)).

261. N. Thane Bauz, Reanimating U.S. Patent Reexamination: Recommendations for Change Based upon a Comparative Study of German Law, 27 CREIGHTON L. REV. 945, 963 (1994).

262. Pegram, supra note 115, at 109-10. Among forty-two civil divisions of the Tokyo District Court, two divisions deal with intellectual property. Id. at 47. Although most cases are handled by a single judge, patent disputes require collegial decision by three judges. Id.

263. Id. at 71. The CAFC was created in 1982. Id. "The Federal Circuit, which is highly specialized, is considered a success," largely because the establishment of the court improved enforcement of the law and eliminated forum shopping. Id. 
Russia may be able to find the most workable model for its patent courts, not in the judicial systems of the United States, Japan, or Germany, but in the English Patents County Court. ${ }^{264}$ The Patents County Court has proved to be an effective venue for the adjudication of patent disputes: it received seventy-seven cases in its first fifteen months and 307 cases in its first four years, and has attracted cases that would not have been brought in other courts. ${ }^{265}$ By contrast, within the U.S. patent system judges trying patent cases often lack special expertise in the area, ${ }^{266}$ and while both Japan and Germany have specialized IP divisions to adjudicate patent infringement disputes, they do not have separate patent courts. Still, the establishment of separate patent courts seems to offer the fastest and most reliable way to provide strong enforcement of patent rights in Russia. While the formation of specialized IP divisions in existing courts would involve overcoming the negative reputations that current courts and judges traditionally have in Russia, ${ }^{267}$ newly-established, independent patent courts would not have to share the reputation of existing courts. A separate system of courts that would hear only patent cases would result in the fast development of "a cadre of skilled judges." 268 These courts could employ special procedures tailored to the specific needs of patent litigants. Technical specialists and scientists, rather than only jurists, could be allowed to become judges in these courts. All of England's Patents County Court judges, for example, have technical knowledge. ${ }^{269}$ As in the Patents County Court, the patent courts in Russia could use simplified procedures in order to allow "a single patent agent familiar with a patent" to initiate an action. ${ }^{270}$ The government could encourage the use of these courts by expediting litigation, decreasing costs, "increasing fines for infringement, and adding additional remedies such as lost profits or treble damages." 271 The availability of patent courts

264. Considering the large territory and population of Russia, one patent court is unlikely to satisfy Russia's needs. A system of regional patent courts may be a more effective solution. In addition, the patent courts' jurisdiction perhaps should not be limited to patent disputes, but should include other IP disputes as well.

265. Pegram, supra note 115, at 106, 108 (citing Alan Burrington, Costs in the Patents County Court, 22 CIPA 26, 30-32 (1993); Alan Burrington, The UK Patents County Court-1s it Working?, PAT. WORLD, Dec. 1991/Jan. 1992, at 41; Letter from The Honourable Peter Ford, Judge of the Patents County Court, to John B. Pegram (July 18, 1994) (on file with the Houston Law Review)).

266. Pegram, supra note 115, at 71 (citing The Advisory Comm'n on Patent Law Reform, Report to the Secretary of Commerce 75 (1992)).

267. For more about the reputation of Russian judges, see supra notes $173-78$ and accompanying text.

268. Stewart, supra note 152 , at 20.

269. Pegram, supra note 115 , at 105 (citing Interview with His Honour Judge Ford, 6 PAT. LITIG. ASS'N NEWSL. 1, 7, 11).

270. Pegram, supra note 115 , at 105-06.

271. Stewart, supra note 152 , at 20. 
with judges knowledgeable in patent law issues would build patent owners' trust in the courts' ability to resolve patent disputes and would encourage patent owners to file lawsuits. Furthermore, it would encourage western companies to bring technologies to Russia, since the technologies would be protected by mechanisms similar to those existing in their home countries.

Another step that the Russian government should take to ensure the adequate protection of patent rights is to provide training for the judiciary on patent legislation and regulation. ${ }^{272}$ Regardless of whether the government decides to form specialized patent courts or leave patent disputes for the courts of general jurisdiction and arbitration courts, most judges in today's Russia lack training and experience in deciding complex patent law issues. ${ }^{273}$ The government needs to provide the necessary means to educate judges involved in patent litigation. The training would be best accomplished with the help of foreign judges who have "special expertise in intellectual property cases, such as the judges of the U.S. Federal Circuit, "274 the judges of the English Patents County Court, the judges of the IP divisions of German and Japanese courts, or judges from other countries who have expertise in the resolution of patent disputes. Local training programs should also be implemented to increase judges' knowledge of patent legislation and of decisions of the Supreme Court on patent law issues. In addition, a comprehensive law journal publishing the courts' decisions on patent law issues is needed to help interpret the law, to allow parties to evaluate their chances in future litigation, and to throw light upon the courts' level of expertise in adjudicating patent disputes. ${ }^{275}$ These few simple actions would ensure conformity in the application of the laws, "further facilitate growth of the legal system," and "help give credibility to the judicial branch." 276

The government must take action to overcome the communal attitude toward inventions (an attitude rooted in the Soviet ideology) held by the Russian population. Russians have to realize that inventions are no longer owned by all the people, ${ }^{277}$ and that using an invention without its owner's permission is theft. ${ }^{278}$ The recognition of patent owners' rights by Russian officials and public and private companies would help stop rampant patent

272. Conference on IP Protection, supra note 164.

273. See supra notes $166-75$ and accompanying text.

274. Stewart, supra note 152, at 21.

275. Specifically, Russia needs a regular and central publication of courts' decisions in a form easily accessible to the public; a journal that perhaps even should be distributed in English to other Patent and Trademark Offices. Stewart, supra note 152, at 21 (citing U.S. Council for International Business, Intellectual Property Committee Working Group on Central Eastern Europe/CIS, at 1 (Mar. 15, 1996) (unpublished manuscript, on file with the Texas Intellectual Property Law Journal)).

276. Stewart, supra note 152, at 20-21.

277. See supra Part II.A.

278. Solton, supra note 18. 
infringement in the country. To provide education on the nature of patent rights, the government needs to organize training seminars covering various aspects of patent law, with emphasis on the consequences of its violation. Involving the media in the process of education could be another way to raise the level of awareness of fundamental patent law concepts among the Russian public.

Finally, the Russian government should improve patenting and licensing of Russian inventions abroad. ${ }^{279}$ Again, seminars for public and private companies and for research and development institutes need to be implemented to explain the need for protecting inventions abroad, the advantages of patenting and licensing abroad, and the process of patenting and licensing in different countries. Since Russian patent owners often lack the money to patent their inventions abroad, the government should consider subsidizing such patents. Adequate protection of Russian technologies abroad would not only facilitate development of innovations in the country, but would also allow Russia to play a more important role in foreign markets. ${ }^{280}$

\section{CONCLUSION}

The past five years have been years of revolutionary change in Russia: the nation has undergone the transition from a socialistic country with a centrally-planned economy to a capitalistic country with "a market economy. ${ }^{\text {28I }}$ This transformation is clearly seen in Russia's reformation of its patent law. The legislation adopted in September 1992 officially ended state ownership of inventions and returned to inventors the exclusivity of ownership that inventors in other countries have enjoyed since the fifteenth century. Unfortunately, merely changing the legislation could not by itself ensure the protection of patent owners' rights. Adoption of the new law did not erase seventy-five years of disregard for IP owners' rights from the minds of the Russian people. This means that the Russian government must now develop and implement an extensive and systematic process of educating the Russian people. More importantly, the Russian government must adopt an effective mechanism for enforcing the existing laws in order to deter infringers from wrongdoing. A workable enforcement mechanism is especially needed given Russia's current political and economic instability. Although other obstacles impede strong patent protection in the country, the lack of a judicial infrastructure that is capable of adjudicating complex patent

279. See supra Part III.C.3.

280. See supra note 212 and accompanying text.

281. US to Review Rules of Trade with Russia, AGENCE FRANCE-PRESSE, Sept. 23, 1997. available in 1997 WL 13400527. 
disputes is the most serious impediment and requires immediate resolution.

In August of 1993, Peter B. Maggs, Corman Professor of Law at the University of Illinois, wrote of Russia's pressing need for an effective patent law judiciary:

Russia has now adopted industrial property legislation generally complying with international standards. However, until it has a strong and functioning commercial court system with serious enforcement powers, there is a great risk that the new legislation will remain on paper. Only backed by a strong judiciary can the laws effectively encourage innovation and high-quality production. 282

At the time of this writing, more than four years after Professor Maggs wrote his essay, Russia still lacks a judicial system capable of providing adequate protection of patent owners' rights. Meanwhile, given the existing economic conditions, Russia's need for a strong patent protection system has become critically urgent. Russia is "decidedly behind the curve in most technologies. "283 Therefore, there is a "crying need for technology transfer as an aid to modernizing" Russia's national economy. ${ }^{284}$ The Russian economy would benefit not only by gaining products imported from production facilities abroad, but also by achieving "large-scale investment in high-technology production facilities employing domestic workers and providing both managerial skills training and an entrepreneurial attitude. ${ }^{285}$ Russia, with the huge potential of its market and its "lack of competition from domestic producers, ${ }^{2286}$ seems to be a particularly attractive country for such technology transfer. However, a strong patent protection system must be in place "to encourage outside investment in high-technology goods and production." 287 Furthermore, Russia's accession to the WTO would be extremely beneficial for the country. ${ }^{288}$ However, the major obstacle to Russia's WTO membership is inadequate protection of intellectual property rights, including the failure to protect the rights of patent owners. Russia has long been famous for the genius of its engineers and scientists. Adequate

282. Peter B. Maggs, Industrial Property in the Russian Federation, in THE REVIVAL, OF

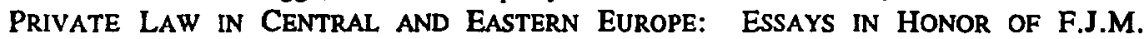
FELDBRUGGE 377, 390 (George Ginsburg et al. eds., 1996).

283. Erickson, supra note 53, at 250.

284. Id.

285. Id. at 251.

286. Theodore K. Smith, Russian Legislation Expands Options Available to Foreign Exporters, RUSS. \& COMMONWEALTH BUS. L. REP., Feb. 12, 1997, available in LEXIS, Europe Library, SBE File.

287. Erickson, supra note 53, at 252.

288. See supra text accompanying notes $2-3$. 
legal protection of Russian inventions both at home and abroad will create incentives for the development of native innovations, thereby helping Russia to gain a respectable position in the global economy.

Marina Portnova*

* J.D. candidate, 1999, Indiana University School of Law-Indianapolis; degree in Soviet patent law, 1990, Institute of Soviet Patent Law, St. Petersburg, Russia; M.S., 1984, B.S., 1982, Technical State University, St. Petersburg, Russia. The author thanks Vladislav Usik, a Russian attorney of ZAO Megadelta in St. Petersburg, Russia, for his help with the research that supports this note. The author also thanks Michael Solton of Steptoe \& Johnson for his helpful suggestions and comments. 
